\title{
Tertiary molluscs of the Scotian Shelf, Atlantic Canada
}

\author{
Fiona E. Cole and Francis C. Thomas* \\ Geological Survey of Canada, Atlantic Geoscience Centre, \\ P.O. Box 1006, Dartmouth, Nova Scotia B2Y 4A2, Canada
}

Date Received July 18, 1995

Date Accepted November 20, 1995

Cuttings from the Cenozoic section of LASMO/NSRL Cohasset Producer CP1 P-51, a production well on the Scotian Shelf, offshore Atlantic Canada, contain relatively large numbers of small molluscs and other microinvertebrates. The stratigraphic distributions of these taxa have been compared with the previously established foraminiferal zonation for this site.

Over 50 species of these fossils are recognized, and many represent extant forms now found in much warmer conditions than presently exist on the Scotian Shelf. Occurrences of most of these warm-water forms are concentrated in the upper portion of the Lower Eocene and lower Middle Eocene, in the lower part of the Oligocene section and, to a lesser extent, in the Lower Miocene, supporting claims for climatic warming trends during these intervals in the foraminiferal literature.

There is some suggestion that at least part of the molluscan assemblage is allochthonous, having been transported into deeper waters from its nearshore origin. If true, this does not affect paleoclimatic interpretations. If the molluscs are in place, fluctuating numbers of these taxa with respect to foraminiferal numbers may suggest differences in the parameters affecting the productivity of the two groups.

The restricted stratigraphic ranges of some of these forms may prove useful in correlations with other Atlantic Canada sites where foraminiferal assemblages are impoverished. In one of the Cohasset species, the serpulid worm Paliurus, the known stratigraphic range appears to be extended from the Eocene up to the Oligocene. A second species, "Coleolus", present in Paleocene to Oligocene horizons, appears to be a homeomorph of a littleknown Palaeozoic form.

The absent or very condensed Upper Eocene section of CP1 P-51 may be related to increased deep-ocean circulation in the Early Oligocene, as suggested in some foraminiferal literature.

Des détritus de la coupe cénozoïque de LASMO/NSRL Cohasset Producer CP1 P-51, un puits productif sur la Plate-forme Scotian, au large des provinces de l'Atlantique, renferment des quantités relativement importantes de petits mollusques et d'autres microinvertébrés. On a comparé les répartitions stratigraphiques de ces taxons avec la zonation des foraminifères de cet endroit réalisée antérieurement.

On reconnaît plus de 50 espèces des fossiles en question; beaucoup représentent des formes encore existantes qu'on trouve aujourd'hui dans des conditions beaucoup plus chaudes que celles actuellement présentes sur la Plate-forme Scotian. La majorité de ces formes d'eaux chaudes sont concentrées dans la partie supérieure de l'Éocène inférieur et la partie inférieure de l'Éocène moyen, dans la partie inférieure de la section de l'Oligocène, ainsi que, dans une moindre mesure, dans le Miocène inférieur, ce qui appuie les allégations de débuts de réchauffement climatique au cours de ces intervalles dans la littérature relative aux foraminifères.

Certains avancent qu'au moins une partie de l'association de mollusques est allochtone et que des mollusques auraient été transportés dans des eaux plus profondes depuis leur littoral d'origine. Le cas échéant, cela n'affecterait pas les interprétations paléoclimatiques. Si des mollusques sont présents, les fluctuations de ces taxons, du point de vue des quantités de foraminiféres, pourraient laisser supposer des différences dans les paramètres affectant la productivité des deux groupes.

Les répartitions stratigraphiques limitées de certaines de ces formes pourraient s'avérer utiles dans les corrélations avec les autres endroits des provinces de l'Atlantique où les associations de foraminifères sont limitées. La répartition stratigraphique de l'une des espèces de Cohasset, le serpule Paliurus, semble s'étendre de l'Éocène à l'Oligocène. Une deuxième espèce, le Coleolus, qui est présente dans les horizons du Paléocène à l'Oligocène, semble être homéomorphe à une forme paléozoïque peu connue.

La section absente ou très concentrée de l'Éocène supérieur du puits CPl P-51 pourrait être reliée à une circulation profonde accrue au cours de l'Oligocène inférieur, comme le supposent certains auteurs dans la littérature relative aux foraminifères.

\section{INTRODUCTION}

[Traduit par la rédaction]

LASMO/NSRL Cohasset Producer CP1 P-51 (hereinafter referred to as CP1 P-51) was one of the first production oil wells to be developed on the Scotian Shelf, offshore Atlantic Canada. It is located in the Cohasset field some $\mathbf{4 0}$ km west of Sable Island, southeast of Nova Scotia (Fig. 1).

* Corresponding author

Atlantic Geology

$32,137-158$ (1996) 


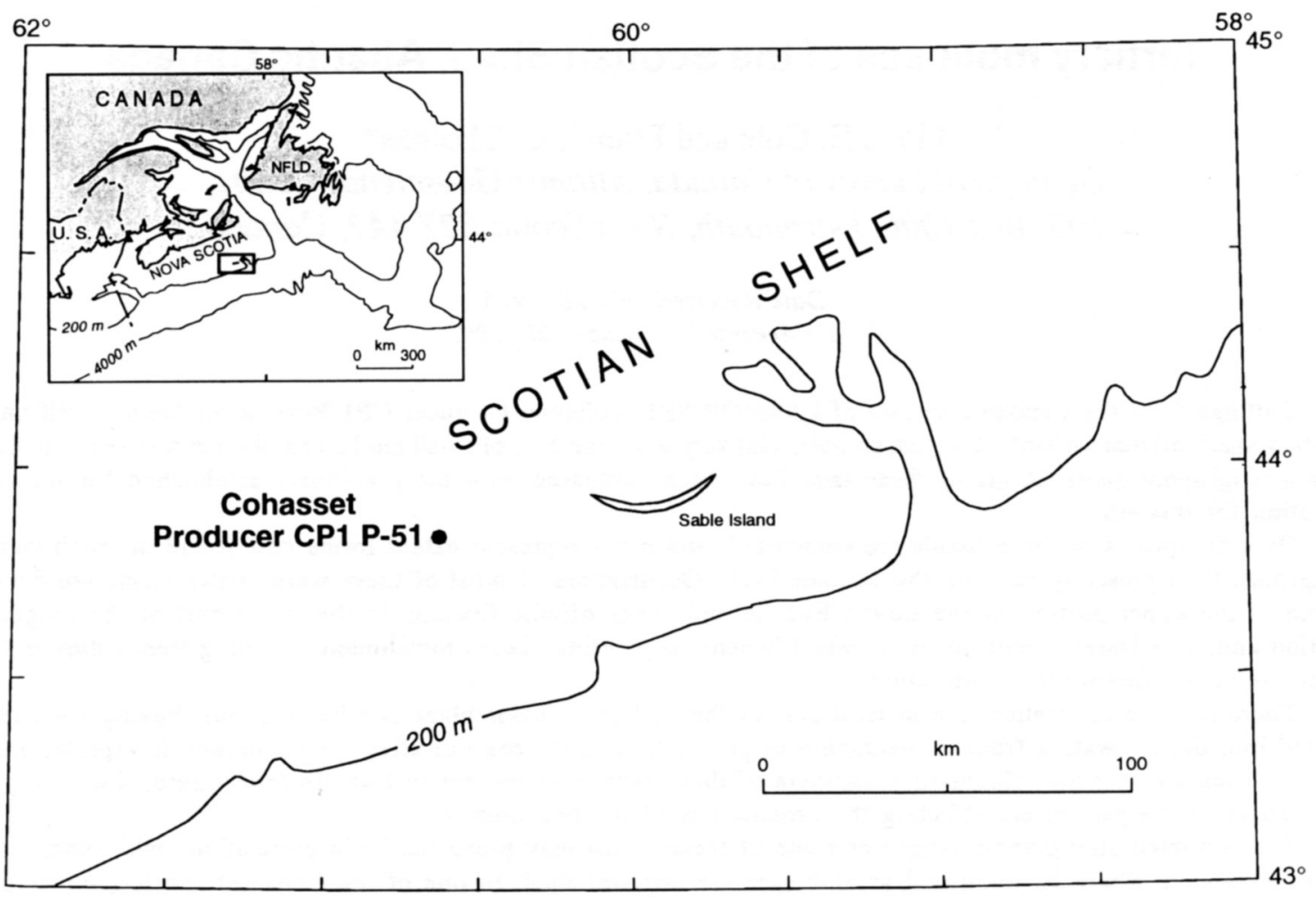

Fig. 1. Location map showing position of Cohasset Producer CP1 P-51.

The Scotian Shelf area has been the scene of intensive hydrocarbon exploration drilling since 1967, with some 140 wells completed by July, 1994. Since biostratigraphic studies of these wells began in the late 1960s, a large body of literature has been produced, concentrating on foraminiferal and ostracode faunas (e.g., Ascoli, 1976; Gradstein and Agterberg, 1982) and palynology (e.g., Barss et al., 1979; Williams et al., 1990).

CP1 P-51 was unusual in the close spacing of the cuttings samples (every $5 \mathrm{~m}$ ) throughout the Tertiary section, collected by the well operator (LASMO Nova Scotia Limited) specifically for detailed biostratigraphic studies. This was done to facilitate a biostratigraphic study of the site on as fine a scale as possible. Technical data and location coordinates for CP1 P-51 are from LASMO Nova Scotia Limited (1993) and are given in Table 1 . The samples were originally processed and analysed for foraminifera by the second author. During this study, the relatively diverse and well-preserved non-foraminiferal taxa were set aside for further study.

Originally, this paper was meant only to catalogue the species of smaller invertebrates and their stratigraphic ranges in CP1 P-51. However, when these data were plotted, patterns emerged which suggested that a number of distinct climatic events had influenced local molluscan faunas during the Cenozoic. Therefore, we have tried to rationalize the molluscan story of this site with the regional biostratigraphic and climatic record, as determined from the foraminifera.

We have chosen the term "smaller invertebrates" to include those fossils, primarily molluscs, which were not foraminifera, ostracodes, or any other of the traditional taxonomic groups used in petroleum biostratigraphy, but were small enough to remain reasonably intact in the CP1 P-51 cuttings samples. The drilling process used in the petroleum industry simply does not permit the recovery of entire fossils larger than a centimetre or so in greatest dimension. Our smaller invertebrates are generally in the size range of one to ten millimetres.

\section{Previous work}

A large amount of work has been done in the last 160 years on the Tertiary molluscan faunas of the western Atlantic region, starting with early works such as Conrad (1835). Most has focussed on macroscopic material from outcrops exposed in various localities on the Atlantic and Gulf Coastal Plains of the eastern United States. An overview of this work prior to 1957 can be found in Gardner and Ladd (1957). Abbott (1974) provides a comprehensive examination of all Recent molluscan species to be found in American waters.

The lack of molluscan studies of material from the Cenozoic wedge of sediments on the eastern continental shelf is due to the relatively large size of these organisms. Even molluscan assemblages in core samples have rarely been systematically examined. Mixon et al. (1989) is one exception; these authors examined material from stratigraphic test holes in Virginia. Richards (1946) also published a brief note on similar materials. Dredge samples from off the eastern American coast have also been examined (Gibson, 1965).

In the Canadian offshore region, a few early studies of rock samples dredged from the Scotian Shelf included descriptions of relatively small molluscan species of Cretaceous and Tertiary ages (Dall, 1925; Stephenson, 1936). Other work has been carried out on Recent and Pleistocene mate- 
Table 1. Technical data on LASMO/NSRL Cohasset Producer CP1 P-51 (from Thomas, 1994).

Location:

Water Depth:

Total Depth Drilled:

Rotary Table Height Above Sea Level: $41.0 \mathrm{~m}$

Rotary Table Height Above Sea Floor: $84.0 \mathrm{~m}$

Interval Studied:

Data Release Date: $43^{\circ} 50^{\prime} 57.180^{\prime \prime} \mathrm{N}, 60^{\circ} 37^{\prime} 39.972^{\prime \prime} \mathrm{W}$

$43.0 \mathrm{~m}$

$2472 \mathrm{~m}$

$170-1010 \mathrm{~m}$

August 5, 1993 rial obtained from outcrops in several localities (e.g., Wagner, 1977), and a catalogue of the Atlantic Geoscience Centre's (Dartmouth, Nova Scotia) collection of molluscan species from various Canadian offshore areas has been prepared (Wagner, 1984). In a few cases, such as described in Schafer and Wagner (1978), living molluscan assemblages have been compared with the foraminiferal biota for certain marine localities.

As far as the present authors have been able to determine, however, this is the first work devoted to the molluscan assemblages from an extensive offshore Canadian Tertiary section and their stratigraphic relationships with the known foraminiferal zonation of the site.

\section{Methods}

Each sample was oven-dried and subsequently weighed. These weights ranged from 100 to over $600 \mathrm{~g}$, but most were between 200 to $400 \mathrm{~g}$. The samples, unconsolidated sands and sandy or silty muds, required no disaggregation; these were simply washed through a stack of sieves, with a 1.700 $\mathrm{mm}$ opening sieve on top, a $0.250 \mathrm{~mm}$ one in the middle and a $0.063 \mathrm{~mm}$ on the bottom. Sample depths (170 to 1010 $\mathrm{m}$ ) and percentages of dry weight $>63$ microns for the 163 samples are listed in Thomas (1994, table 2). The washed residues were then dry-sieved and a small portion of the $>0.150 \mathrm{~mm}$ cut was examined and hand-picked for microfossil content.

The foraminiferal analysis of this Cenozoic section has been previously published (Thomas, 1994), and the resulting ages of strata are the standard used here (Fig. 2).

Microphotography for the plates was undertaken using Kodak Tech-Pan $35 \mathrm{~mm}$ film in a Leitz Aristophot, a device incorporating a camera body, an extendible bellows and interchangeable lenses.

Figured specimens are stored in the Mollusc Collection at the Geological Survey of Canada (Atlantic), Dartmouth, Nova Scotia.

In determining the stratigraphic boundaries of CP1 P51 or any well entirely from cuttings, only the uppermost occurrence (the LAD (Last Appearance Datum) or stratigraphic exit) of a given marker species can have significant stratigraphic value; its earliest or lowest occurrence (FAD (First Appearance Datum) or stratigraphic entrance) may be artificially low because of downhole caving. The sandy and unconsolidated nature of many of the sediments resulted in severe caving, with the result that microfossil assemblages in many levels contain numerous demonstrably younger taxa as contaminants.

The zonation used for the foraminiferal study was that proposed by Gradstein and Agterberg (1982), a quantitative scheme based on optimum sequences of common Tertiary microfaunal elements of the Canadian Atlantic Margin including benthic and planktic foraminifera, and a few other taxa such as diatoms and pteropods.

\section{Geological SeTting}

The Scotian Shelf (Fig. 1) has an average width of 200 $\mathrm{km}$ and a present average depth of some $125 \mathrm{~m}$. It is underlain by sedimentary formations spanning most of the Mesozoic and Cenozoic. From the Middle Jurassic on, these units are largely marine in origin and in places total several kilometres in thickness.

By the beginning of the Tertiary, fine grained clastic sediments were being deposited in water depths of 200 to $600 \mathrm{~m}$ on the central part of the Scotian Shelf, in the vicinity of the Cohasset field. Ongoing subsidence of the region permitted the accumulation of Cenozoic marine sediments up to $1500 \mathrm{~m}$ thick in some places (Wade and MacLean, 1990).

The depositional unit encompassing all of the Tertiary on the Scotian Shelf is the Banquereau Formation (Williams et al., 1985), which also includes Santonian to Maastrichtian sediments (Wade and MacLean, 1990). In general in this area, the Banquereau appears to represent nearly continuous, southeasterly prograding mudstones, grading upwards into more or less unconsolidated sands and conglomerates. Hardy (1975) proposed a subdivision of this formation into four component units, but this scheme has not been widely followed. At CP1 P-51 the top of the Banquereau lies somewhere above the top of sampling at $170 \mathrm{~m}$, and the base lies uncomformably on the Late Cretaceous Wyandot Formation (Thomas, 1994). Quaternary material was not sampled. Several unconformities, apparently subaqueous, have been delineated within the Cenozoic sections of many parts of the Scotian Shelf, and have been documented biostratigraphically (Ascoli, 1976; Barss et al., 1979). 


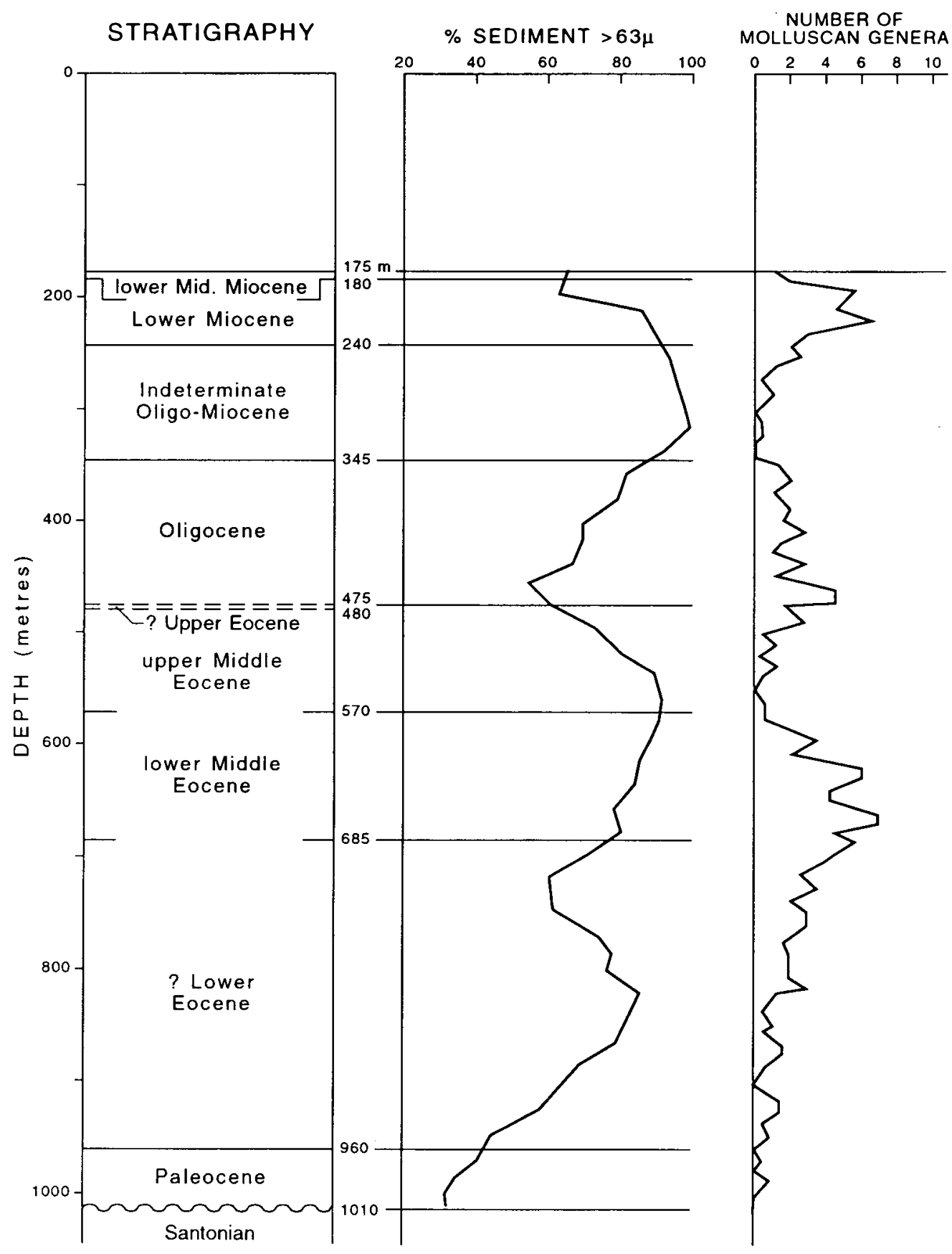

Fig. 2. Biostratigraphy of Cohasset Producer CP1 P-51 showing ages derived from Foraminifera (from Thomas, 1994), \% sediment $>63 \mu$, and numbers of molluscan genera.

At the CP1 P-51 site, foraminiferal assemblages through the Cenozoic section indicate the following history (Thomas, 1994): Lower Paleocene sediments are missing, but more or less continuous deposition in a middle to upper bathyal (i.e., water depths of 200 to $1000 \mathrm{~m}$ ) setting occurred from the early Late Paleocene to at least late Middle Eocene time. These sediments rest unconformably at this site on the Wyandot Formation, a chalky unit containing foraminifera of Santonian age (Piero Ascoli, personal communication, 1994). The benthic foraminiferal faunas of the Paleocene to upper Middle Eocene were mostly calcareous in nature, and relatively few planktics were found. Common Late Cretaceous foraminifera in these levels indicate sourcing from an unknown eroding Mesozoic outcrop.

During the Late Eocene, deposition at the site was reduced and may even have ceased for a time. Abundant glauconite at this level suggests an extended interval of nondeposition at no greater than upper bathyal depth $(\sim 200 \mathrm{~m})$ (Thc mas, 1994).

Oligocene and Miocene assemblages attest to the continued shallowing at CPI P-51 as sediments accumulated, and coarser clastic materials in these levels suggest increasing sedimentological dynamism. 


\section{Results}

The smaller invertebrates found in the Cenozoic of this site include at least 24 gastropod species (at least 22 genera), 15 bivalve species (13 genera), six scaphopod taxa (3 genera), two genera of solitary corals, and a serpulid worm. These taxa may comprise up to $70 \%$ of the total microfossils in a sieved fraction of a few samples, but generally average about $5 \%$, including unidentifiable bivalve and gastropod fragments.

The stratigraphic distribution of these taxa is given in Figures 3, 4 and 5. Occurrences of species in samples are indicated by a presence/absence designation. Numbers of specimens of each taxon in a sample were not considered because of the somewhat unquantitative nature of the picking. However, the approximate percentage of the total fossil assemblage in each sample comprised of molluscs or mollusc fragments was noted and is given in Figure 6, along with estimates of numbers of foraminifera per sample, and occurrences of the most common invertebrate taxa.

The data can be summarized as follows: The only identifiable smaller invertebrates in the Paleocene (960-1010 $\mathrm{m}$ ) were a few fragments that represent a form very like the scaphopod Coleolus originally described by Hall (1879).

In the Lower Eocene section (685-960 m), "Coleolus" sp. is common, and other scaphopods include Dentalium cf. D. callithrax Dall and Dentalium occidentale Stimpson. Rare bivalves include Astarte cf. A. undata Gould, Crassostrea cf. C. virginica (Gmelin), Dacrydium vitreum (Hollböll), and slightly larger numbers of Glycymeris cf. G. americana (De France). The ten gastropod taxa are Buccinum cf. $B$. plectrum Stimpson, Diastoma cf. D. alternatum (Say), Heliacus spp., Turbonilla cf. T. emertoni Verrill, Odostomia sp., Retusa sp., Solariella cf. S. lamellosa Verrill and Smith and Turritellellopsis cf. T. acicula (Stimpson) and two indeterminate species. Of these, only Heliacus spp., Retusa sp. and Solariella cf. S. lamellosa Verrill and Smith are restricted to the Lower Eocene; the other taxa are present in the overlying Middle Eocene section. Coelenterates are represented by a single specimen of Caryophyllia sp.

The Middle Eocene can be divided by the foraminiferal assemblages into a lower (570-685 m) and an upper (485$570 \mathrm{~m}$ ) half (Fig. 2), based on the uppermost occurrence of Acarinina densa (Cushman) as outlined by Gradstein and Agterberg (1982). This division is also reflected in the molluscan assemblages. The lower half contains at least twelve species of gastropods. The more common forms include Alvania cf. A. acuticostata (Dall), Buccinum cf. B. plectrum Stimpson, Turbonilla cf. T. emertoni Verrill, and Turritellopsis cf. T. acicula (Stimpson). The most common bivalve is Glycymeris cf. G. americana (De France). Bathyarca centenaria (Say), Crassostrea cf. C. virginica (Gmelin) and Glycymeris cf. G. subtilis (Nicol) also occur repeatedly, whereas three species are represented by individual specimens. Scaphopods are present in larger numbers than other molluscs, especially Dentalium cf. $D$. callithrax Dall, $D$. occidentale Stimpson and "Coleolus" sp. If our identification is accurate, this latter taxon was previously known only from Palaeozoic mate-

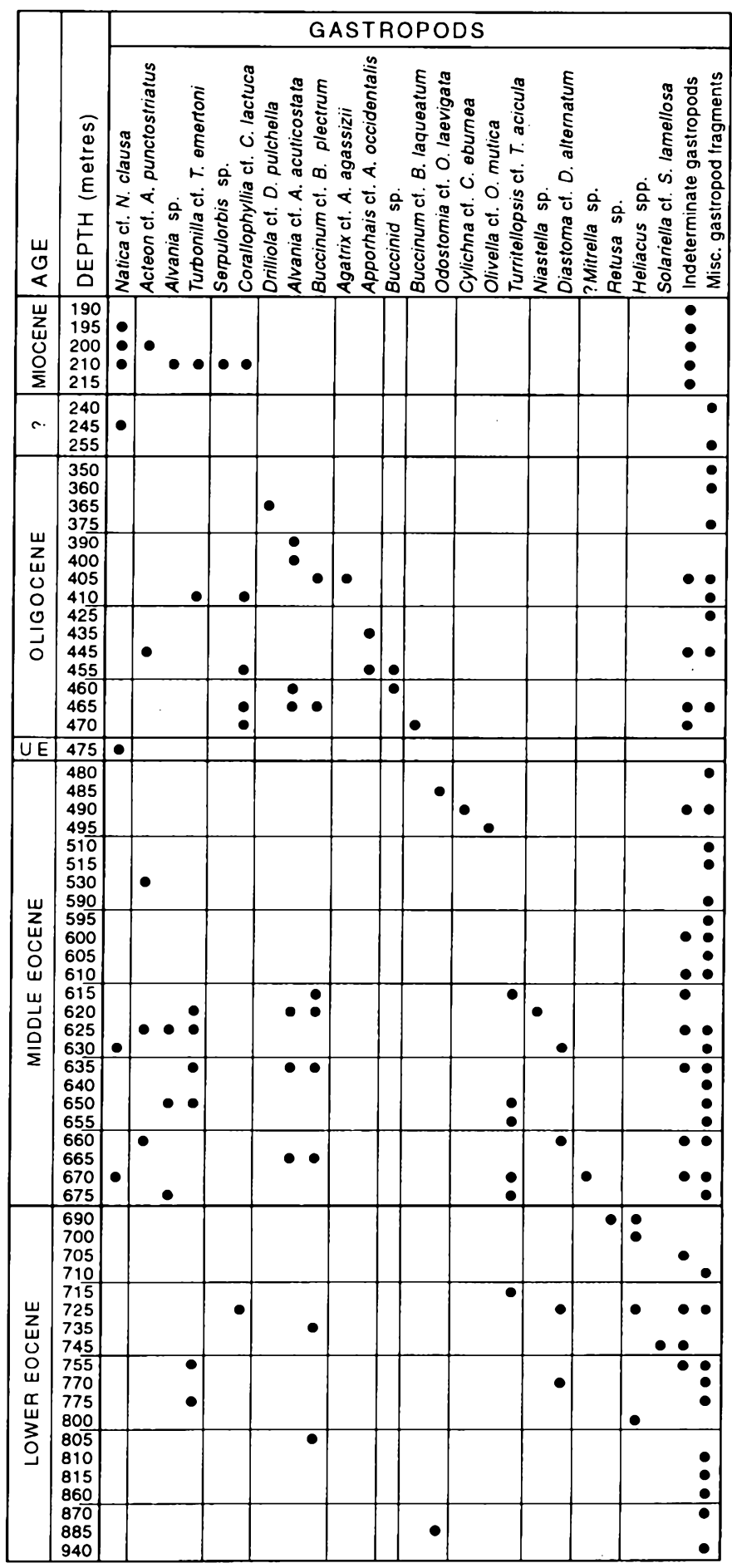

Fig. 3. Stratigraphic distribution of gastropod taxa in Cohasset Producer CP1 P-51.

rial (Hall, 1879). The serpulid worm Paliurus spp. also occurs in small numbers.

In contrast, the upper Middle Eocene assemblages are sparser, with five gastropod species (represented by one or two indivuals), four bivalves, and substantially fewer scaphopods than in the underlying material. Again, some of these individuals may be caved from overlying sections, while a few, the gastropods Odostomia sp., Cylichna cf. C. eburnea Verrill and Olivella cf. O. mutica (Say) and the bivalve Dacrydium 


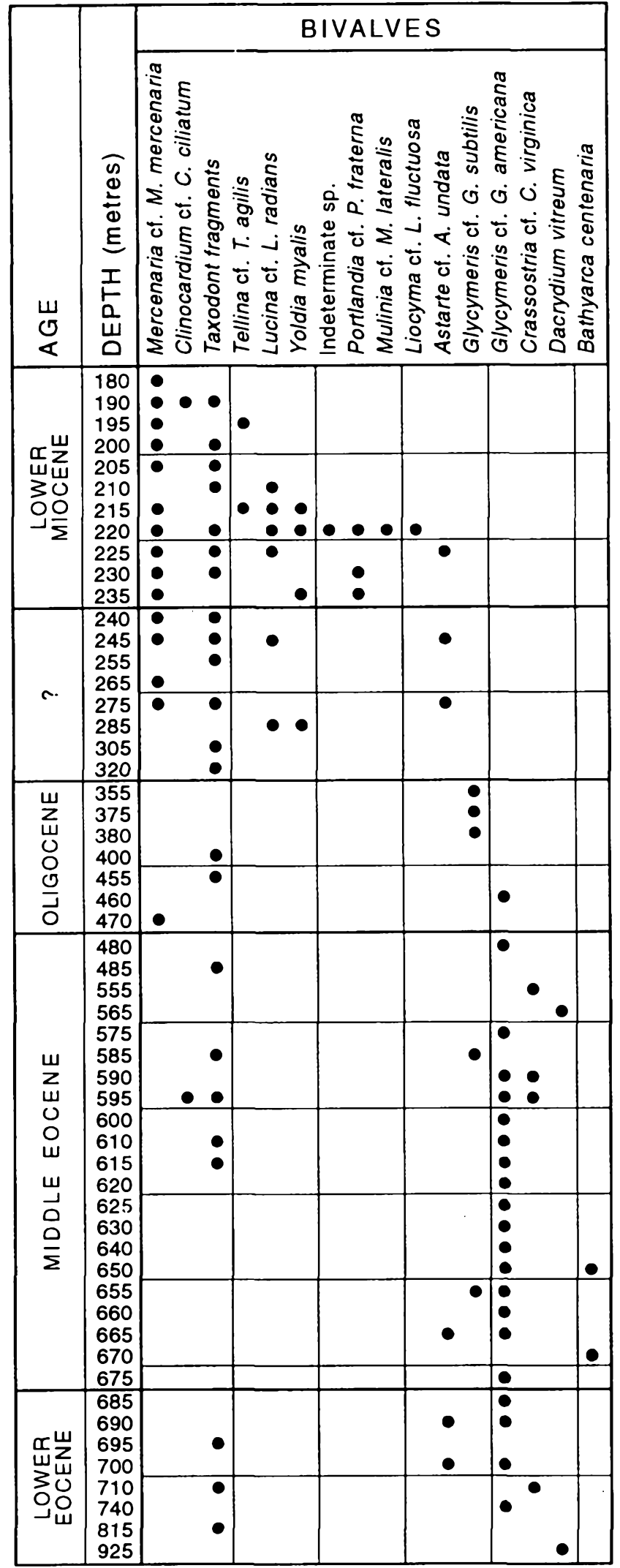

Fig. 4. Stratigraphic distribution of bivalve taxa in Cohasset Producer CP1 P-51.

vitreum (Hollböll), have their $\mathrm{LAD}$ in this level. A single sample at $475 \mathrm{~m}$ probably represents a very condensed Upper Eocene section, and contains a molluscan assemblage similar to that of the overlying Oligocene, although an unknown proportion of these taxa may represent caved material.
The Oligocene (345-475 m) contains some 12 gastropod taxa, including the LADs of Alvania cf. $A$. acuticostata (Dall) and Buccinum cf. B. plectrum Stimpson, among others. Bivalves are much less important, with only three recognizable species. The LADs of two of these, Glycymeris cf. G. americana (De France) and Glycymeris cf. G. subtilis (Nicol), are in this section. The other, a single specimen of Mercenaria cf. M. mercenaria (Linné), may be caved from above. The scaphopods include essentially the same forms as below. Several specimens of corals occur near the bottom of this section, the largest concentration of these fossils in the Cenozoic. The serpulid genus Paliurus, represented by at least two species, has its LAD here and is common.

The Oligocene or Lower Miocene indeterminate section above this, from 240 to $345 \mathrm{~m}$, with the coarsest average clast size in the Cenozoic, contains a single identifiable gastropod (Natica cf. N. clausa Broderip and Sowerby), small numbers of four bivalve species, and a single scaphopod (Dentalium sp.).

The Lower Miocene section overlying this (180-240 m) is much richer, including eight species of gastropods and eight bivalve taxa, dominated by Mercenaria cf. M. mercenaria (Linné), Lucina cf. L. radians (Conrad), Portlandia cf. $P$. fraterna (Verrill and Bush) and Yoldia sp. The small scaphopod component is dominated by Dentalium occidentale Stimpson.

\section{Discussion}

The Cenozoic stratigraphic record of the smaller invertebrate species at this site displays a number of features of interest to regional Cenozoic sedimentary and paleoceanographic history. In particular, it appears to contain evidence of several major faunal events, roughly correlative to oceanic circulation/climatic phenomena known from the foraminiferal record.

The exact provenance of the bivalves and gastropod species in the Paleocene, Eocene and Oligocene sections of the well, where the foraminiferal evidence suggests a middle to upper bathyal water depth, are unclear. It is entirely possible that some or all of these forms are allochthonous, having been transported downslope from shallower areas. Small numbers of Late Cretaceous planktic foraminifera in many of these samples indicate reworking of material from elsewhere, clearly demonstrating some hydrological dynamism in this environment (Thomas, 1994). In a nearby analogous setting, Elmore et al. (1979) reported long-distance downslope transport of small mollusc shells recovered from the Hatteras Abyssal Plain. Further evidence of possible transport of at least some of these forms lies in the abraded, worn appearance of many tests. Fragments of shells are also quite common, but it is unclear how much of this damage may have resulted from drilling.

Many of the mollusc specimens found appear similar or identical to modern species known from the southeastern coast of the United States (Abbott, 1974). Since the foraminifera indicate deeper water, these shells are most probably not in situ.

Whether the bivalves and gastropods are partially or 

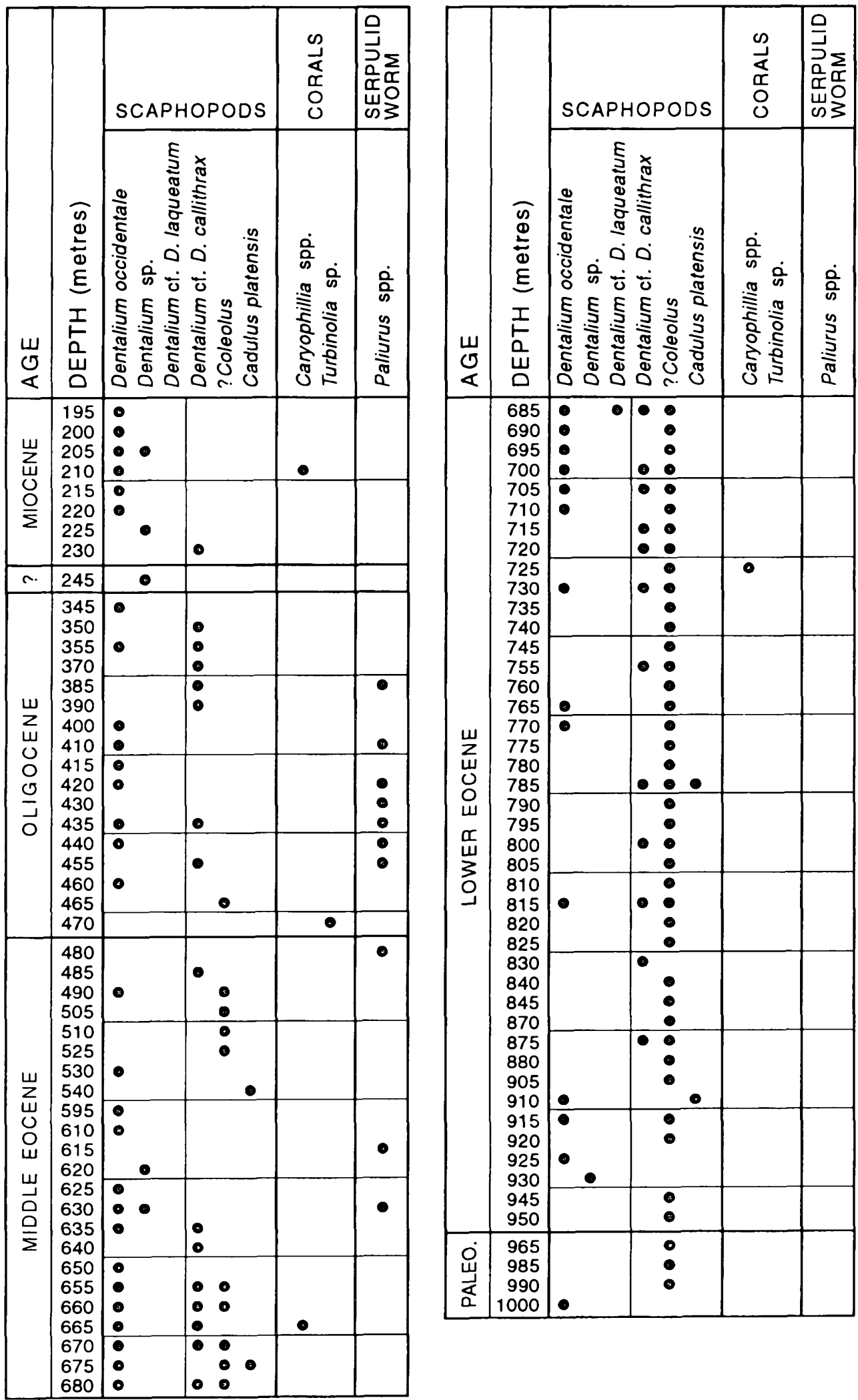

Fig. 5. Stratigraphic distribution of scaphopods, corals and Paliurus spp. in Cohasset Producer CPI P-51.

all transported to the site from upslope or are in situ, does not invalidate climatic interpretations based on the assemblages, provided they are not reworked from significantly older strata. Indeed, regional warming and cooling trends would tend to have more effect in local neritic areas than in bathyal depths as in the Paleogene at this site, where many benthic foraminiferal species tend to be more cosmopolitan in distribution (van Morkhoven et al., 1986).

Figure 6 shows the downhole distributions of the ten stratigraphically most long-ranging mollusc species (i.e., 

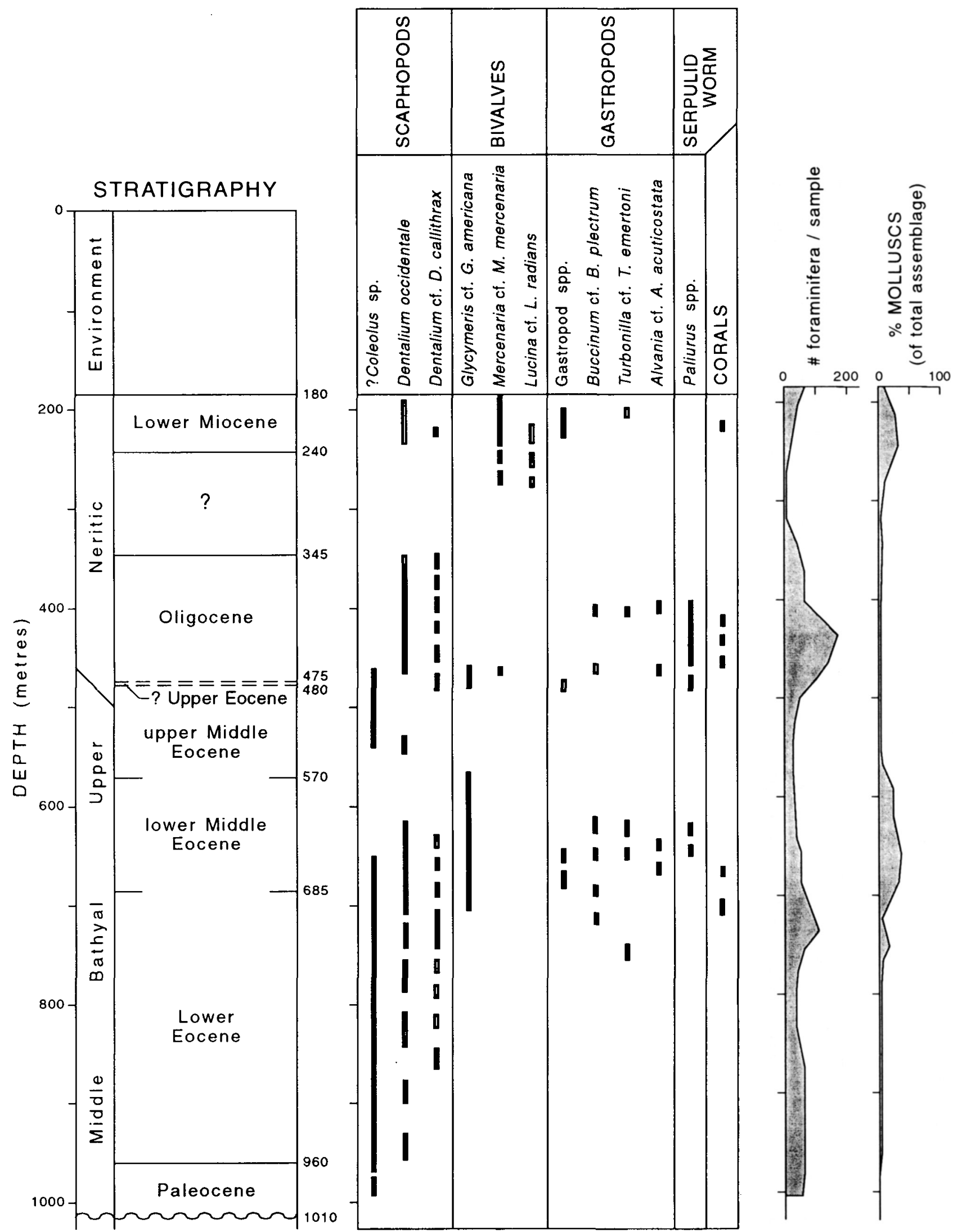

Fig. 6. Occurrences of most common smaller invertebrate taxa in Cohasset Producer CP1 P-51, along with estimates of total foraminifera per sample and molluscs or mollusc fragments as a percentage of the total microfossil assemblage.

those occurring in eight or more samples), the common serpulids Paliurus spp. and the rare corals. Also shown are the percentages of microfossil preparations comprised of molluscs or mollusc fragments, and the numbers of foraminiferal tests in the samples. These last two figures as shown are averaged over approximately $35 \mathrm{~m}$ intervals. 
The preponderance of scaphopods in the Paleocene and most of the Early Eocene is probably related to the middle bathyal water depth in this interval. The scaphopod genus Cadulus and species Dentalium callithrax appear to prefer open shelf to upper slope environments (Abbott, 1974).

Near the top of the Lower Eocene section, and continuing into the lowermost Middle Eocene, small numbers of several gastropod species and one bivalve appear. The bivalve, Glycymeris cf. G. americana (De France), and two of the gastropods, Alvania cf. A. acuticostata (Dall) and Heliacus cf. $H$. sigsbeei (Dall), are considered to be warmer-water forms (see Appendix). The first appearance of the serpulid Paliurus and a few corals also occur in this interval. It is not clear from this record whether warming in upslope, shallower areas had occurred at this time, or if the site had simply shoaled enough to reach the lower depth limits of organisms already established in the warmer, shallower water. One of the scaphopods, Dentalium of. D. callithrax Dall, possibly also indicative of relatively warm conditions, is present at the site from near the beginning of the Eocene, which tends to suggest the second scenario.

Around the mid-point of the Middle Eocene all of these warmer indicators disappear temporarily. Although the cuttingsbased chronostratigraphic control is imprecise (Thomas, 1994), this disappearance may reflect the climatic cooling documented by Miller (1992) from oxygen isotope studies of foraminiferal tests from about this time throughout the North Atlantic regionally, and other locations.

The upper half of the Middle Eocene section probably contains only scaphopods; the very few bivalves, gastropods and Paliurus specimens at the top of this interval are all seen in overlying material and may well represent cavings. The later half of the Middle Eocene, according to Keller $e t$ al. (1992) was a time of widespread surface water cooling in low latitudes, possibly linked to pulses in Antarctic glaciation. They found that this climatic shift had a greater impact on surface-dwelling planktic foraminifera than on intermediate or deep-dwelling taxa. Because taxa living in shallow conditions would also tend to be affected more by this cooling trend, the disappearance of much of the smaller invertebrate fauna in the Cohasset site appears to be reasonably correlated to this cooling event even if the fauna is derived from an upslope source. Miller (1992) summarizes current information on the widespread occurrence of erosional events about the base of the Oligocene. The evidence suggests that deep-water circulation was much more vigorous during the Early Oligocene than previously, and is thought to have been related to the formation of bipolar ice sheets. The hiatus or very condensed section at the Cohasset site in the Upper Eocene occurs to varying degrees at a few other Scotian Shelf sites (Ascoli, 1976; F.C. Thomas, unpublished data), and may be an expression of this climatic change, possibly as a result of enhanced or invigorated circulation at depth.

The Oligocene section of Cohasset contains the same gastropods as occur in the Eocene, though in slightly smaller numbers. The worm Paliurus, previously only known from Eocene and older sediments (Gabb, 1876), is well repre- sented, and the corals also re-appear, along with small numbers of the bivalve Glycymeris cf. G. americana (De France). A single specimen of another bivalve, Mercenaria cf. $M$. mercenaria (Linné), may well be caved. Two scaphopods, including the presumably warm-water Dentalium of. $D$. callithrax Dall, re-appear. With the exception of the scaphopods, however, the molluscs and corals all disappear again well before the top of the Oligocene section.

Possibly this brief "warm" interval may relate in some way to the temporary disappearance of the Oligocene ice sheets postulated by Miller et al. (1987). Furthermore, Keller et al. (1992) describe evidence for a second Antarctic glaciation pulse or sudden cooling event at mid-Oligocene time, which may have been responsible for the second extirpation before the end of the Oligocene. Hansen (1992) has demonstrated the sensitivity of Paleogene molluscan shelf faunas to changes in temperature in the Gulf Coast area, showing that molluscan diversity drops significantly in response to lowered temperatures.

If many of the molluscs at CP1 P-51 are reworked from a contemporaneous upslope source, the apparent increase in numbers in the lower Oligocene may simply be a result of an increase in shoreline erosion due to the Oligocene glacioeustatic sea level drop documented by Miller et al. (1987), among others. Its composition as stated above, however, still suggests a relatively warm neritic environment, at least during the initial phase of this regression.

The smaller invertebrate fauna of the Lower Miocene is somewhat less clear in its climatic associations. The scaphopods are less common, possibly a result of the significantly shallower conditions, as evidenced by the foraminifera (Thomas, 1994). The most common bivalve is Mercenaria cf. $M$. mercenaria, but the warm water indicator Lucina cf. $L$. radians is also present. A few specimens of unidentified gastropods are present, some of which seem to correlate positively with the two previous "warm" intervals. A single coral also occurs.

Miller et al. (1987) mentioned evidence of a possible second temporary absence or reduction of glaciation in the Early Miocene. Perhaps a somewhat tenuous correlation with this event could be argued for this fauna, although its character is admittedly ambiguous.

The ocean circulation history and neritic climatic evidence suggested by the molluscs and other smaller invertebrates for the site cannot be substantiated by the foraminiferal record (Thomas, 1994). The foraminifera, being predominantly benthic and overwhelmingly in situ (except for downhole caving contamination), are principally upper to mid-bathyal (i.e., 200 to $1000 \mathrm{~m}$ water depth) in habitat (except for the outer neritic Lower Miocene section) and thus show no major climatic variations. Many are well-known species described as cosmopolitan in the literature (e.g., Tjalsma and Lohmann, 1983; van Morkhoven et al., 1986).

There appears to be no clear correlation between absolute numbers of foraminifera and proportion of molluscs (Fig. 6). In Oligocene levels, for instance, where the foraminifera are most abundant and diverse, numbers of molluscs are low. In the upper Lower Eocene, lower Middle Eocene 
and Lower Miocene, where foraminiferal assemblages are less rich, the molluscs are more abundant. These data would tend to suggest either that foraminiferal productivity and molluscan productivity are regulated by different mechanisms, or, perhaps more likely, that the molluscan component is at least partly allochthonous, and its relative numbers within the stratigraphic column have more to do with pulses of downslope transport than the in situ benthic environment.

Alternatively, when the numbers of molluscan genera, arguably a better measure of faunal richness, are compared to the \% sediment $>63 \mu$, an inverse relationship is seen, at least above the mid-Lower Eocene, where gastropods and bivalves become more common (Fig. 2). Higher numbers of genera appear to correlate positively with sections of lower sand and silt components. Assuming that much of the sedimentary input from upslope is coarser material, this tends to suggest that at least some bivalves and gastropods are in fact, endemic at depth.

Finally, this study also extends the known ranges of two invertebrate taxa. The serpulid worm genus Paliurus Gabb, previously known only from Eocene levels, occurs at the Cohasset site through the Oligocene. Much more dramatically, the known range of the enigmatic "Coleolus", which we believe to be a scaphopod, is now extended from the $\mathrm{Pa}$ leozoic up into the Oligocene. This huge apparent increase in stratigraphic range strongly indicates that our species is an unrelated homeomorph of Hall's (1879) species. For now, we choose to retain the name because of its close resemblance to Hall's original description.

\section{Conclusions}

The smaller invertebrates of the microfossil assemblages in the Cenozoic section of Cohasset Producer CP1 P-51 appear to provide some background climatic information to the paleoenvironments of their source areas. Conclusions to be drawn from this study are:

(1) It is unclear whether the majority of bivalves and gastropods found in the well are in situ or were transported downslope from a shallower source area.

(2) If most of the molluscan fauna is in situ, the fluctuating numbers relative to foraminifera suggest productivity of the two groups is dependent on different factors.

(3) The relatively large numbers of warm water forms among the smaller invertebrates suggest somewhat warmer conditions than at present for the source environments of these taxa. The sporadic occurrences of these warm indicators may reflect climatic warmings in the lower Middle Eocene, Oligocene and possibly Early Miocene.

(4) Certain common species such as the bivalve Glycymeris cf. $G$. americanus and the gastropods Buccinum cf. $B$. plectrum and Alvania cf. $A$. acuticostata show restricted stratigraphic ranges which may prove to be useful in local Cenozoic biostratigraphy, often appearing in samples fairly poor in foraminifera.

(5) The serpulid worm Paliurus, previously known only from the Eocene, ranges up into the Oligocene at this site.
(6) We have discovered a probable scaphopod species closely resembling Hall's (1879) Palaeozoic "Coleolus" in sediments of Paleocene to Oligocene age in this site. We regard our form as an unrelated homeomorph, however, because of the great stratigraphic gap between the two species.

(7) The very condensed or absent Upper Eocene section in this site may be an expression of enhanced deep circulation during the Early Oligocene, as postulated in some of the foraminiferal literature.

\section{ACKNowledgements}

Many thanks to Terry P. Poulton (GSC Calgary) and Graham L. Williams (GSC Atlantic) for many helpful suggestions in the preparation of this manuscript. Thanks also to Nelly Koziel (GSC Atlantic) for word processing and Rhonda Coulstring who drafted the figures. This is Geological Survey of Canada Contribution No. 55694.

Аввотт, R. 1974. American sea shells (2nd edition). Van Nostrand Reinhold Company, New York, 663 p.

Ascolı, P. 1976. Foraminiferal and ostracod biostratigraphy of the Mesozoic-Cenozoic, Scotian Shelf, Atlantic Canada. In Proceedings of the 1st International Symposium on Benthonic Foraminifera of Continental Margins, Part B, Paleoecology and Biostratigraphy. Maritime Sediments, Special Publication 1, pp. 653-771.

Barss, M.S., Bujak, J.P., and Williams, G.L. 1979. Palynological zonation and correlation of sixty-seven wells, eastern Canada. Geological Survey of Canada, Paper 78-24, 118 p.

Conrad, T.A. 1835. Observations on a portion of the Atlantic Tertiary region. Geological Society of Pennsylvania Transactions, 1, pp. 335-341.

...- 1841. On the palaeontology of the state of New York. New York State Geological Survey, 5th Annual Report, pp. 2527.

--.-- 1893. Fossil shells of the Tertiary formations of North America illustrated by figures drawn on stone, from nature. Originally published 1832-1837. Republication by G.D. Harris, 1893.

DALL, W.H. 1925. Tertiary fossils dredged off the Northeastern Coast of North America. American Journal of Science, 5th series, 10, pp. 213-218.

Elmore, R.D., Pilkey, O.H., Cleary, W.J., and Curran, H.A. 1979. Black shell turbidite, Hatteras Abyssal Plain, western Atlantic Ocean. Geological Society of America Bulletin, 90, pp. 1165-1176.

Feyling-Hansen, R.W. 1955. Stratigraphy of the marine Late Pleistocene of Billefjorden, Vestspitsbergen. Norsk Polarinstitutt Skrifter, $107,186 \mathrm{p}$.

Fisher, D.W. 1962. Small conoidal shells of uncertain affinities. In Treatise on Invertebrate Paleontology, Part W - Miscellanea. Edited by R.C. Moore. Geological Society of America and University of Kansas Press, pp. W98-W143.

GABB, W.M. 1876. Notes on American Cretaceous fossils, with descriptions of some new species. Proceedings of the Academy of Natural Sciences of Philadelphia, pp. 276-324.

GARDNER, J.A. and LADD, H.S. 1957. Cenozoic mollusks of the Atlantic and East Gulf coastal plains: annotated bibliography. In Paleoecology. Edited by H.S. Ladd. Geological Society of America, Memoir, pp. 885-886. 
Gibson, T.G. 1965. Eocene and Miocene rocks off the northeastern coast of the United States. Deep-Sea Research, 12, pp. 975-981.

Gmelin, J.F. 1791. Caroli a Linné Systema naturae per regna tria naturae. Editio decima tertia, G.E. Beer. Leipzig, 1, pp. 3021-3910.

Gradstein, F.M. and Agterberg, F.P. 1982. Models of Cenozoic foraminiferal stratigraphy - Northwestern Atlantic Margin. In Quantitative Stratigraphic Correlation. Edited by J.M. Cubitt and R.A. Reyment. John Wiley and Sons Limited, Chichester, United Kingdom, pp. 119-174.

Hall, J. 1879. Containing descriptions of the Gastropoda, Pteropoda, and Cephalopoda of the Upper Helderberg, Hamilton, Portage, and Chemung groups. Natural History of New York, Paleontology, 5, $113 \mathrm{p}$.

HANSEN, T. 1992. The patterns and causes of molluscan extinction across the Eocene-Oligocene boundary. In Eocene-Oligocene Climatic and Biotic Evolution. Edited by D.R. Prothero and W.A. Berggren. Princeton University Press, Princeton, New Jersey, pp. 341-348.

HARDY, I.A. 1975. Lithostratigraphy of the Banquereau Formation on the Scotian Shelf. In Offshore Geology of Eastern Canada, 2. Edited by B.R. Pelletier. Geological Survey of Canada, Paper 74-30, pp. 163-174.

Howell, B.F. 1962. Worms. In Treatise on Invertebrate Paleontology, Part W - Miscellanea. Edited by R.C. Moore. Geological Society of America and University of Kansas Press, pp. W144-W177.

Keller, G., MacLeod, N., and Barrera, E. 1992. Eocene-Oligocene faunal turnover in planktic foraminifera, and Antarctic glaciation. In Eocene-Oligocene Climatic and Biotic Evolution. Edited by D.R. Prothero and W.A. Berggren. Princeton University Press, Princeton, New Jersey, pp. 218-243.

Lasmo Nova Scotia Limited. 1993. LASMO/NSRL Cohasset CP1 Well History. LASMO/NSRL, Halifax, Nova Scotia, 19 p. + appendices.

LuDBROOK, N.H. 1960. Scaphopoda. In Treatise on Invertebrate Paleontology, Part I, Mollusca 1. Edited by R.C. Moore. Geological Society of America and University of Kansas Press, pp. I137I141.

MilleR, K.G. 1992. Middle Eocene to Oligocene stable isotopes, climate, and deep-water history: the terminal Eocene event? In Eocene-Oligocene Climatic and Biotic Evolution. Edited by D.R. Prothero and W.A. Berggren. Princeton University Press, Princeton, New Jersey, pp. 160-177.

Miller, K.G., Fairbanks, R.G., and Mountain, G.S. 1987. Tertiary oxygen isotope synthesis, sea level history, and continental margin erosion. Paleoceanography, 2, pp. 1-19.

Mixon, R.B., Powars, D.S., Ward, L.W., and Andrews, G.W. 1989. Lithostratigraphy and molluscan and diatom biostratigraphy of the Haynesville cores; outer coastal plain of Virginia. In Geology and Paleontology of the Haynesville Cores - Northeastern Virginia Coastal Plain. Edited by R.B. Mixon. United States Geological Survey, Professional Paper 1489, pp. Al-A48.

Morton, J.E. 1979. Molluscs (5th Edition). Hutchinson and Company, London, $264 \mathrm{p}$.

Richards, H.G. 1946. Studies on macrofossils from deep wells along the Atlantic Coast. Oil and Gas Journal, 44, p. 93. 1962. Studies on the marine Pleistocene, Part 2. The marine Pleistocene mollusks of Eastern North America. Transactions of the American Philosophical Society, new series, 52, pp. 42-141.

Schafer, C.T. and Wagner, F.J.E. 1978. Foraminifera-mollusc associations in eastern Chaleur Bay. Canadian Journal of Earth Sciences, 15, pp. 889-901.

Stephenson, L.W. 1936. Geology and Paleontology of the Georges Bank Canyons, Part II. Upper Cretaceous fossils from Georges Bank (including species from Banquereau, Nova Scotia). Bulletin of the Geological Society of America, 47, pp. 367410.

SYssolev, V.A. 1957. K morfologii, sistematischeskomu polozhennyv i sistematike kholitov. Akademie Nauk SSSR Leningrad, Doklady, 116, pp. 304-307. [On the morphology, systematic position, and systematics of Hyolithoidea.]

Tномas, F.C. 1994. Cenozoic micropaleontological biostratigraphy of LASMONSRL Cohasset Producer CP1 P-51, Scotian Shelf. Atlantic Geology, 30, pp. 113-121.

Tualsma, R.C. and Lohmann, G.P. 1983. Paleocene-Eocene bathyal and abyssal benthic foraminifera from the Atlantic Ocean. Micropaleontology, Special Publication 4, Micropaleontology Press, New York, 90 p.

Van Morkhoven, F.P.C.M., Berggren, W.A., and Edwards, A.S. 1986. Cenozoic cosmopolitan deep-water benthic foraminifera. Bulletin des Centres de Recherches Exploration-Production Elf-Aquitaine, Memoir 11, Pau, 1986, 421 p.

Verrill, A.E. 1882. Catalogue of the marine Mollusca added to the fauna of the New England region during the past ten years. Transactions of the Connecticut Academy, 5, pp. 447 587; Second Catalogue, ibid., 6, pp. 139-294; Third Catalogue, ibid., 6, pp. 395-452.

WAdE, J.A. and MacLean, B.C. 1990. The geology of the southeastern margin of Canada, Chapter 5. In Geology of the Continental Margin of Eastern Canada. Edited by M.J. Keen and G.L. Williams. Geological Survey of Canada, Geology of Canada, 2, pp. 167-238.

Wagner, F.J.W. 1977. Palaeoecology of Marine Pleistocene Mollusca, Nova Scotia. Canadian Journal of Earth Sciences, 14, pp.13051323.

...-.- 1984. Illustrated catalogue of the Mollusca (Gastropoda and Bivalvia) in the Atlantic Geoscience Centre index collection. Geological Survey of Canada, Ottawa, 76 p.

Wells, J.W. 1956. Scleractinia. In Treatise on Invertebrate Paleontology, Part F - Coelenterata. Edited by R.C. Moore. Geological Society of America and University of Kansas Press, pp. F328-F444.

Williams, G.L., Fyffe, L.R., Wardle, R.J., Colman-Sadd, S.D., and Boenner, R.C. 1985. Lexicon of Canadian Stratigraphy, VI, Atlantic region. Canadian Society of Petroleum Geologists, Calgary, $572 \mathrm{p}$

Williams, G.L., Ascoli, P., Barss, M.S., Bujak, J.P., Davies, E.H., Fensome, R.A., and Williamson, M.A. 1990. Biostratigraphy and related studies, Chapter 3. In Geology of the Continental Margin of Eastern Canada. Edited by M.J. Keen and G.L. Williams. Geological Survey of Canada, Geology of Canada, 2, pp. 87-137. (Also Geological Society of America, the Geology of North America, I-1.)

Editorial Responsibility : R.K. Pickerill 


\section{APPENDIX \\ Systematic paleontology}

Information on the individual taxa of smaller invertebrates of CP1 P-51 is provided in this section. Since this is not a formal systematic taxonomic treatment of these fossils, the classifications are simplified from standard, wellknown texts; for the corals Wells (1956); for the worms Howell level) by Morton (1979); and for the scaphopods Ludbrook (1960).

A "Remarks" section for each taxon outlines the known stratigraphic range and present depth range. For the molluscs, the latter is, unless otherwise noted, taken from Abbott (1974). Formal descriptions, along with synonymy lists, are beyond the scope of this paper, particularly since most of the molluscan forms at least are well known; in some cases, however, circumstances warrant a few notes on the size, condition or appearance of the specimens.

The "Levels" section lists the samples in which each taxon was found and outlines the stratigraphic distribution of the form at CP1 P-51.

\section{Phylum Coelenterata Frey and Leuckart, 1847 Class Anthozoa Ehrenberg, 1834 \\ Order Scleractinia Bourne, 1900 Family Caryophylliidae Gray, 1847} (1962); for the gastropods and bivalves (down to the family

Genus Turbinolia Lamarck, 1816 Turbinolia sp.

Fig. 7.7, 7.8

Remarks: This genus is restricted to Eocene-Oligocene in the Atlantic realm. Wells (1956) gives no depth range. Our specimen is conical, $5 \mathrm{~mm}$ in length, with markedly fewer septae than the Caryophyllia spp.

Levels: $\mathbf{4 7 0} \mathrm{m}$, base of Oligocene.

\section{Phylum Annelida Lamarck, 1809 \\ Class Polychaetia Grube, 1850 \\ Order Sedentarida Lamarck, 1818 \\ Family Serpulidae Burmeister, 1837}

\section{Genus Paliurus Gabb, 1876 \\ Paliurus spp.}

Fig. 7.17 to 7.19

Remarks: First described by Gabb (1876), from the Eocene of North America. We have found no further references to it in the literature. Several specimens were found, belonging mostly to one species, with one or two specimens that appear to belong to a second species. All are fragments of slightly curved calcareous tubes which exhibit a more or less triangular cross section, with a round central cavity. Most are under $2 \mathrm{~mm}$ in length.

Levels: $630,615,480,455,440,435,430,420,410,385$ $\mathrm{m}$. Occurrences of this genus in Oligocene sediments extend its known stratigraphic range from the Eocene.

\section{Phylum Mollusca \\ Class Gastropoda \\ Order Archaeogastropoda Thiele, 1925 \\ Family Trochidae Rafinesque, 1815}

Remarks: Solitary corals of this genus range from Upper Jurassic to Recent and are cosmopolitan from 0 to $2700 \mathrm{~m}$ depth (Wells, 1956). Three of the four coral specimens found appear to belong to this genus; they are apparently of at least two species. All specimens are single and measure less than $10 \mathrm{~mm}$ in length.

Levels: 725, 665, $455 \mathrm{~m}$. Lower Eocene to Lower Miocene.

\section{Genus Solariella Wood, 1842}

Solariella cf. S. lamellosa Verrill and Smith, 1880 Fig. 8.1

Remarks: In the modern Atlantic, $S$. lamellosa is found from Massachusetts to the West Indies; 30 to $300 \mathrm{~m}$ is its

Fig. 7. Corals and scaphopods. Scale bar $=1 \mathrm{~mm} .(7.1,7.2)$ Caryophyllia sp. coral from $665 \mathrm{~m}$. Side and top views of same specimen. GSC no. 78502. (7.3, 7.4) Caryophyllia sp. coral from $860 \mathrm{~m}$. Side and top views of same specimen. GSC no. 78503. (7.5, 7.6) Caryophyllia sp. coral from $850 \mathrm{~m}$. Side and top views of same specimen. GSC no. 78504. (7.7, 7.8) Turbinolia sp. coral from $470 \mathrm{~m}$. Side and top views of same specimen. GSC no. 78505. (7.9, 7.10) Dentalium cf. D. callithrix. 7.9 from $355 \mathrm{~m}$. GSC no. 78506. 7.10 from $755 \mathrm{~m}$. GSC no. 78507. (7.11, 7.12) Dentalium cf. D. laqueatum from $685 \mathrm{~m}$. GSC 78508.7 .11 is a drawing to illustrate the surface ornamentation. $(7.13,7.14)$ Dentalium sp. Both from $630 \mathrm{~m} .7 .14$ is a cross sectional view showing round internal cavity and ribs. GSC no. 78509 (7.13) and GSC no. 78510 (7.14). (7.15, 7.1) “Coleolus" sp. from 630 m. GSC no. 78510. 7.15 is a drawing to show the oblique striae. $(7.17,7.18)$ Paliurus sp. (serpulid) from $425 \mathrm{~m}$. GSC no. 78511 . Note triangular cross section of shell. (7.19) Paliurus sp. from $385 \mathrm{~m}$. GSC no. 78512. Note more rounded cross section. (7.20) Dentalium occidentale from $195 \mathrm{~m}$. GSC no. 78513. (7.21) Cadulus cf. C. platensis from $540 \mathrm{~m}$. GSC no. 78514. (7.22) Shark tooth from $195 \mathrm{~m}$. GSC no. 78515. This is the largest intact fossil tooth taken so far from offshore Nova Scotia wells. 


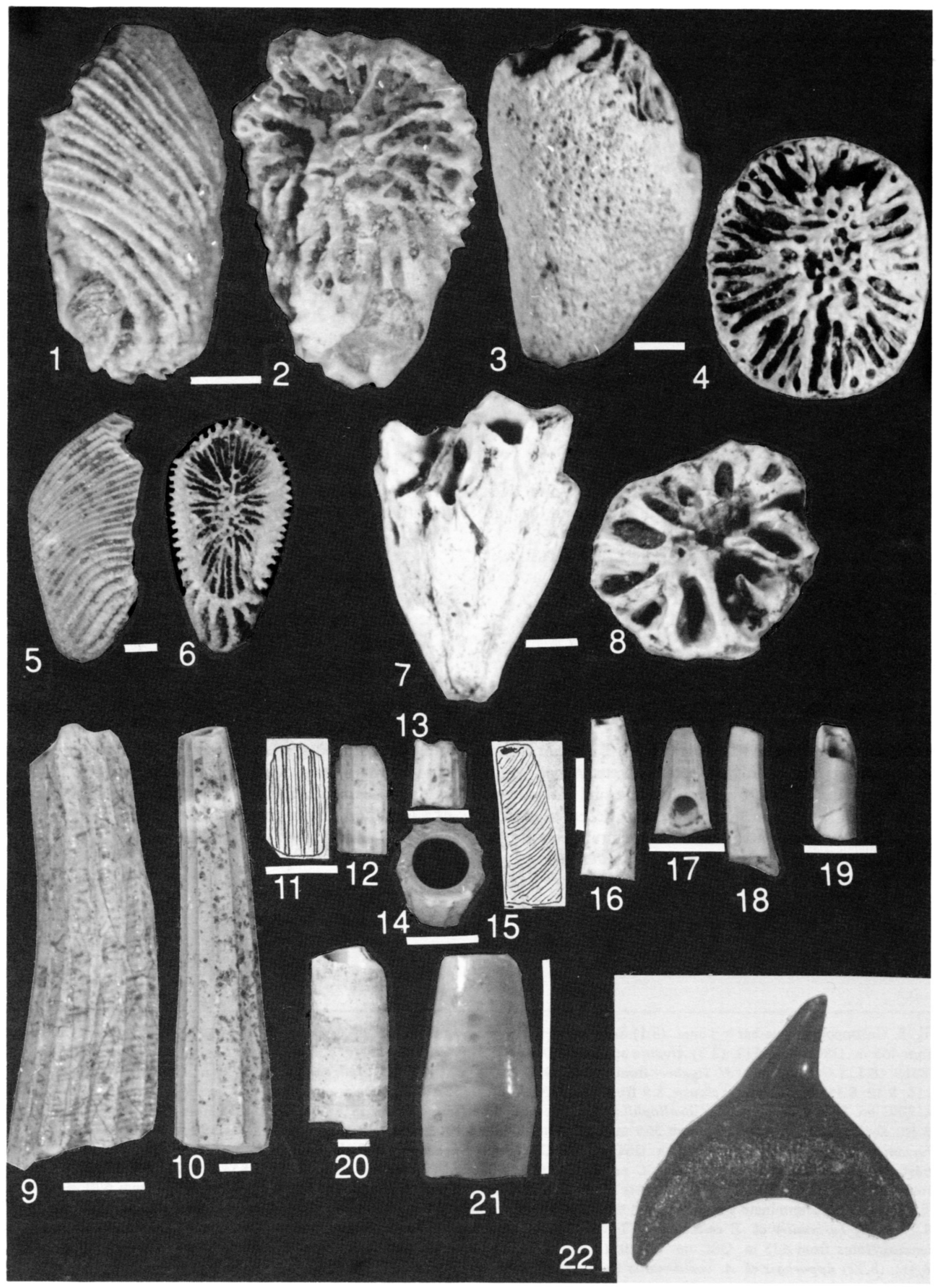


usual depth range, but has been recorded from $1400 \mathrm{~m}$. From this information, the single, well-preserved, $3 \mathrm{~mm}$ specimen we found may well have been in situ rather than transported.

Levels: $745 \mathrm{~m}$, just below the Oligocene-Eocene boundary.

\section{Order Mesogastropoda}

Family Rissoidae Gray, 1847

\section{Genus Alvania Risso, 1826 \\ Alvania cf. A. acuticostata (Dall, 1889)}

Fig. 8.2

Remarks: At present, $A$. acuticostata ranges from North Carolina to Barbados and is found at depths from 60 to 1300 m.

Levels: $665,635,620,465,460,400,390 \mathrm{~m}$. Several specimens in Oligocene and lower Middle Eocene strata.

\section{Alvania sp.}

Fig. 8.3

Remarks: This alvanid carries the characteristic spiral lines on the protoconch, but in this form they carry on through the entire shell.

Levels: $675,650,625,210 \mathrm{~m}$. One specimen at $210 \mathrm{~m}$ (Lower Miocene), a few more in lower Middle Eocene.

\section{Family Turritellidae Clarke, 1851}

\section{Genus Turritellopsis G.0. Sars, 1878}

Turritellopsis cf. T. acicula (Stimpson, 1851)

Fig. 9.6 to 9.9

Remarks: According to Richards (1962), T. acicula is now found in waters from Labrador to Massachusetts. Abbott (1974) concurs, giving 10 to $100 \mathrm{~m}$ depth as its usual bathymetric range. Its wide range in shallow areas of Recent seas indicates that it tolerates a variety of temperature conditions. Our specimens were mostly in the 1 to $2 \mathrm{~mm}$ size range.
Levels: $715,675,670,655,650,615 \mathrm{~m}$. Several specimens in lower Middle and Lower Eocene samples.

\section{Family Architectonicidae Gray, 1850}

\section{Genus Heliacus d'Orbigny, 1842 \\ Heliacus cf. H. sigsbeei (Dall, 1889) \\ Fig. 8.5, 8.6}

Remarks: At present, $H$. sigsbee is a subtropical form, found from Florida to Barbados, in water to $600 \mathrm{~m}$ depth. Given this present geographic range, the very similar form in CP IP51 could perhaps also be considered a warm-water indicator. All specimens are in excellent condition, and approximately $1 \mathrm{~mm}$ in diameter.

Levels: 700, $800 \mathrm{~m}$. Several specimens in Lower Eocene levels.

\section{Heliacus sp.}

Fig. 8.7, 8.8

Remarks: These low-spired, umbilicate forms appear to belong to Heliacus, but are too damaged or smooth to attribute confidently to $H$. sigsbeei.

Levels: 725, 700, 690 m. A few specimens in Lower Eocene.

\section{Family Vermetidae Rafinesque, 1815}

\author{
Genus Serpulorbis Sassi, 1827 \\ Serpulorbis sp. \\ Fig. 9.11, 9.12
}

Remarks: Serpulorbids are found today in tropical, shallow water. At lengths of about $2.5 \mathrm{~mm}$, our two trochospiral, irregularly coiled specimens are probably juveniles, lacking the longitudinal cording diagnostic of adults. They may belong to $S$. decussatus (Gmelin, 1791), but identification of a juvenile is uncertain at best.

Levels: 210 m (Lower Miocene).

Fig. 8. Gastropods. Scale bar $=1 \mathrm{~mm}$. (8.1) Solariella cf. S. lamellosa from $745 \mathrm{~m}$. GSC no. 78516. (8.2) Alvania cf. A. acuticostata from $465 \mathrm{~m}$. GSC no. 78517. (8.3) Alvania sp. from $210 \mathrm{~m}$. GSC no. 78518. (8.4) Diastoma cf. D. alternatum from $650 \mathrm{~m}$. GSC no. 78519. (8.5, 8.6) Heliceus of $\mathrm{H}$. sigsbeei from $700 \mathrm{~m}$. GSC no. 78520. (8.7, 8.8) Heliceus sp. from $725 \mathrm{~m}$. GSC no. 78521 . (8.9, 8.10, 8.11, 8.12, 8.13) Natica cf. $N$. clausa. 8.9 from $210 \mathrm{~m}$. GSC no. $78522.8 .10,8.11$ from $630 \mathrm{~m}$. GSC no. $78523.8 .12,8.13$ from 475 m. GSC no. 78524. (8.14, 8.15) Corallophila cf. C. lactuca. 8.14 from $470 \mathrm{~m}$. GSC no. 78525.8 .15 from $1045 \mathrm{~m}$. GSC no. 78526. (8.16) Drilliola cf. D. pulchella from $365 \mathrm{~m}$. GSC no. 78527. (8.17) Indeterminate gastropod from $455 \mathrm{~m}$. GSC no. 78528. (8.18) Buccinum cf. B. plectrum from $775 \mathrm{~m}$. GSC no. 78529. (8.19) Buccinum cf. B. laqueatum from $470 \mathrm{~m}$. GSC no. 78230 . (8.20) Indeterminate gastropod from $195 \mathrm{~m}$. GSC no. 78531. (8.21) Buccinid? from $460 \mathrm{~m}$. GSC no. 78532. (8.22) Olivella cf. O. mutica from $495 \mathrm{~m}$. GSC no. 78533. (8.23) Agatrix cf. A. agassizii from $405 \mathrm{~m}$. GSC no. 78534. (8.24) Mitrella sp. from $670 \mathrm{~m}$. GSC no. 78535. (8.25) Indeterminate gastropod from $620 \mathrm{~m}$. GSC no. 78536. (8.26) Odostomia cf. O. laevigata from $485 \mathrm{~m}$. GSC no. 78537. (8.27, 8.28) Turbonilla cf. T. emertoni. 8.27 from $210 \mathrm{~m}$. GSC no. 78538.8 .28 from $410 \mathrm{~m}$. GSC no. 78539. (8.29) Acteon cf. A. punctostriatus from $445 \mathrm{~m}$. GSC no. 78540. (8.30, 8.31) Indeterminate gastropods from $470 \mathrm{~m}$. GSC no.78541 (8.30) and 78542 (8.31). (8.32) Apporhais cf. A. occidentalis from $435 \mathrm{~m}$. GSC no. 78543. 


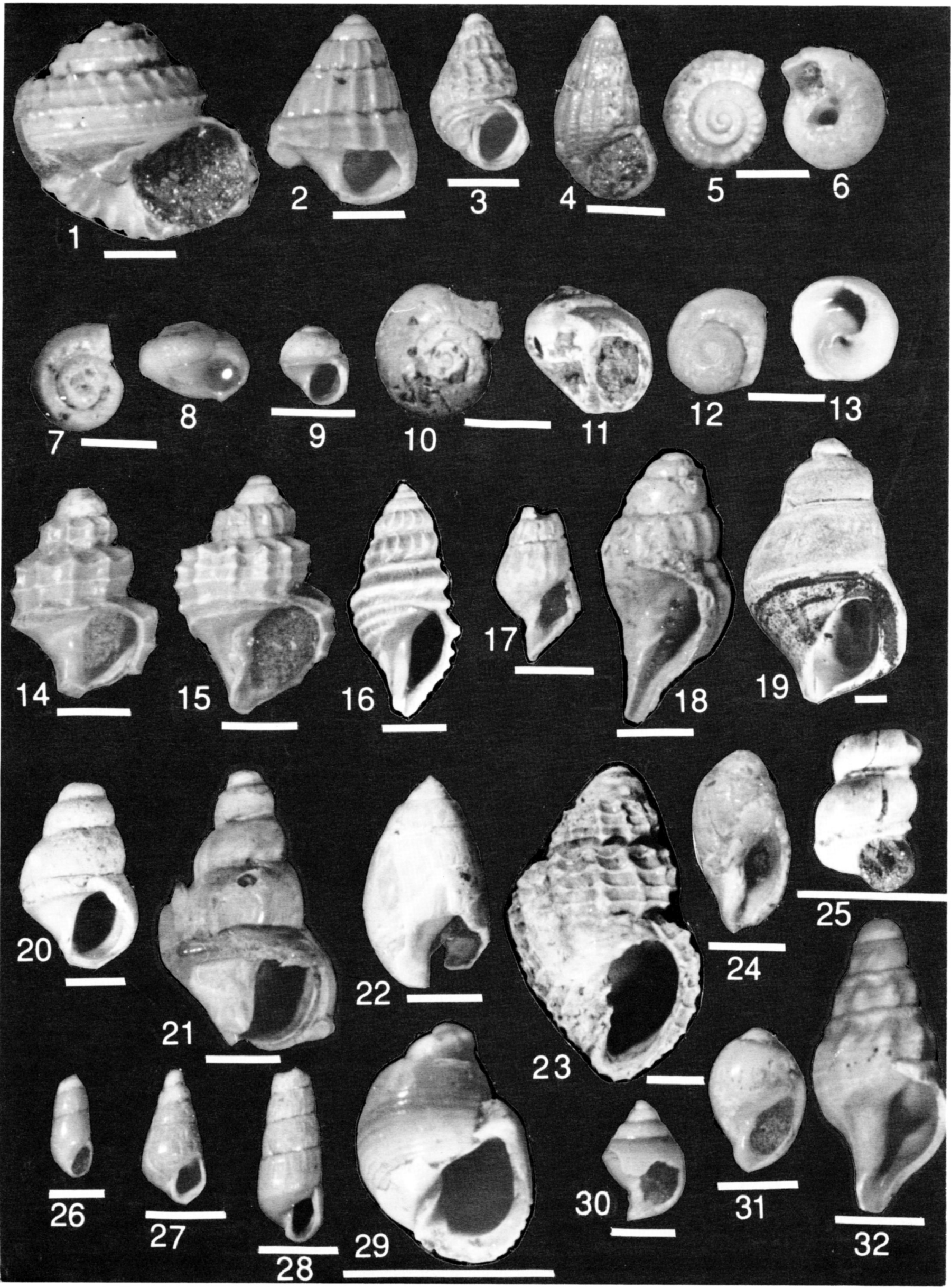


Family Cerithiidae Fleming, 1822

\section{Genus Diastoma Deshayes, 1850}

Diastoma cf. D. alternatum (Say, 1822)

Fig. 8.4

Remarks: Currently ranging from the Gulf of St. Lawrence to coastal Virginia, D. alternatum is usually found in waters shallower than $40 \mathrm{~m}$ (Abbott, 1974). The specimens are very similar to this species. Given its present broad geographic range it appears to be another fairly tolerant taxon. Its present shallow depth range suggests that this form may be part of a transported, allochthonous element in CP1 P51.

Levels: 770, 725, 660, $630 \mathrm{~m}$. Lower and lower Middle Eocene.

Family Apporhaidae Morch, 1852

Genus Apporhais da Costa, 1778

Apporhais cf. A. occidentalis Beck, 1836

Fig. 8.32

Remarks: Richards (1962) describes the range of the apparently tolerant form $A$. occidentalis as from the Gulf of St. Lawrence to North Carolina. Abbott (1974) agrees, giving its bathymetric distribution as subtidal to $700 \mathrm{~m}$. Our very similar specimens range up to $4 \mathrm{~mm}$ in length.

Levels: $455,435 \mathrm{~m}$. Small numbers in two lower Oligocene samples.

\section{Family Naticidae Gray, 1840}

\section{Genus Natica Scopoli, 1777}

Natica cf. N. clausa Broderip and Sowerby, 1829

Fig. 8.9 to 8.13

Remarks: Richards (1962) describes $N$. clausa as found from Arctic Canada to North Carolina, as does Abbott (1974), in depths to $2400 \mathrm{~m}$. Feyling-Hansen (1955) records $N$. clausa as widespread in the northern regions of the Atlantic, preferring shallower water in the north, deeper water towards the south. Our specimens are probably $N$. clausa, but are too damaged for positive identification. Given its present depth range, this form may well have been endemic at the Cohasset site.

Levels: $670,630,475,245,210,200,195 \mathrm{~m}$. Scattered samples from lower Middle Eocene to Lower Miocene.
Family Coralliophilidae Chenu, 1859

\author{
Genus Coralliophila Chenu, 1859 \\ Coralliophila cf. C. lactuca Dall, 1889 \\ Fig. 8.14, 8.15
}

Remarks: The present geographic range of $C$. lactuca is Florida and the Gulf of Mexico, at 300 to $550 \mathrm{~m}$ water depth. Our closely related forms may also represent warm conditions, possibly in shallower areas upslope.

Levels: $725,470,465,455,410,210 \mathrm{~m}$. Sèveral specimens in the lower Middle Eocene, one in Oligocene and small numbers in Lower Miocene.

\section{Order Neogastropoda \\ Family Columbellidae Swainson, 1840}

\author{
Genus Mitrella Risso, 1826 \\ ?Mitrella sp. \\ Fig. 8.24
}

Remarks: This specimen appears to be a Mitrella, but is too badly worn for certain identification.

Levels: $670 \mathrm{~m}$ (lower Middle Eocene).

\section{Family Buccinidae Rafinesque, 1815}

\section{Genus Buccinum Linné, 1758 \\ Buccinum cf. B. plectrum Stimpson, 1865 \\ Fig. 8.18}

Remarks: Richards (1962) indicates the present distribution of $B$. plectrum as from the Arctic to the Gulf of St. Lawrence, as does Abbott (1974). In all our specimens only the initial part of the shell is intact.

Levels: $805,735,665,635,620,615,465,405 \mathrm{~m}$. Several specimens occur in Lower and lower Middle Eocene and Oligocene samples.

\section{Buccinum cf. B. laqueatum Con rad, 1841 Figs. 8.19, 9.13}

Remarks: Conrad (1841) originally described $B$. laqueatum from the Upper Tertiary (Miocene) of the eastern seaboard of the United States. The specimen figured in Plate 2 (fig. 19) is a juvenile, that in Plate 3 (fig. 13) is a large (10 10 $\mathrm{mm}$ ) fragment of an adult.

Fig. 9. Gastropods and bivalves. Scale bar $=1 \mathrm{~mm} .(9.1,9.2,9.3,9.4,9.5)$ Indeterminate Gastropods. 9.1 from $445 \mathrm{~m}$. GSC no. 78544. 9.2 from $405 \mathrm{~m}$. GSC no. 78545. 9.3 from $4 \mathrm{~m}$. GSC. no. 78546.9 .4 from $465 \mathrm{~m}$. GSC no. 78547.9 .5 from $635 \mathrm{~m}$. GSC no. 78548. (9.6, 9.7, 9.8, 9.9) Turritellopsis cf. T. acicula. 9.6 from $670 \mathrm{~m}$. GSC no. 78549. 9.7, 9.8 from $675 \mathrm{~m}$. GSC no. 78550 (9.7) and GSC no. 78551 (9.8). 9.9 from $650 \mathrm{~m}$. GSC no. 78552. (9.10) Cylichna cf. C. eburnea from $490 \mathrm{~m}$. GSC no. 78553. (9.11, 9.12) Serpulorbis sp. from $210 \mathrm{~m}$. GSC no. 78554. (9.13) Buccinum cf. B. laqueatum from $1035 \mathrm{~m}$. A relatively large fragment of a later whorl. GSC no. 78555. (9.14, 9.15) Yoldia myalis from $235 \mathrm{~m}$. GSC no. 78556. (9.16) Portlandia cf. P. fraterna from $215 \mathrm{~m}$. úsC no. 78557. (9.17) Retusa sp. from $690 \mathrm{~m}$. GSC no. 78558. $(9.18,9.19)$ Bathyarca centenaria $670 \mathrm{~m}$. GSC no. 78560. (9.20) Taxodont hinge fragment from $200 \mathrm{~m}$. GSC no. 78559. (9.21, 9.22, 9.23, 9.24) Glycymeris cf. G. americana. $9.21,9.22$ from $665 \mathrm{~m}$. GSC no. 78561. 9.23, 9.24 from $650 \mathrm{~m}$. GSC no. 78562 . $(9.25,9.26)$ Glycymeris cf. G. subtilis from $655 \mathrm{~m}$. GSC no. 78563. 


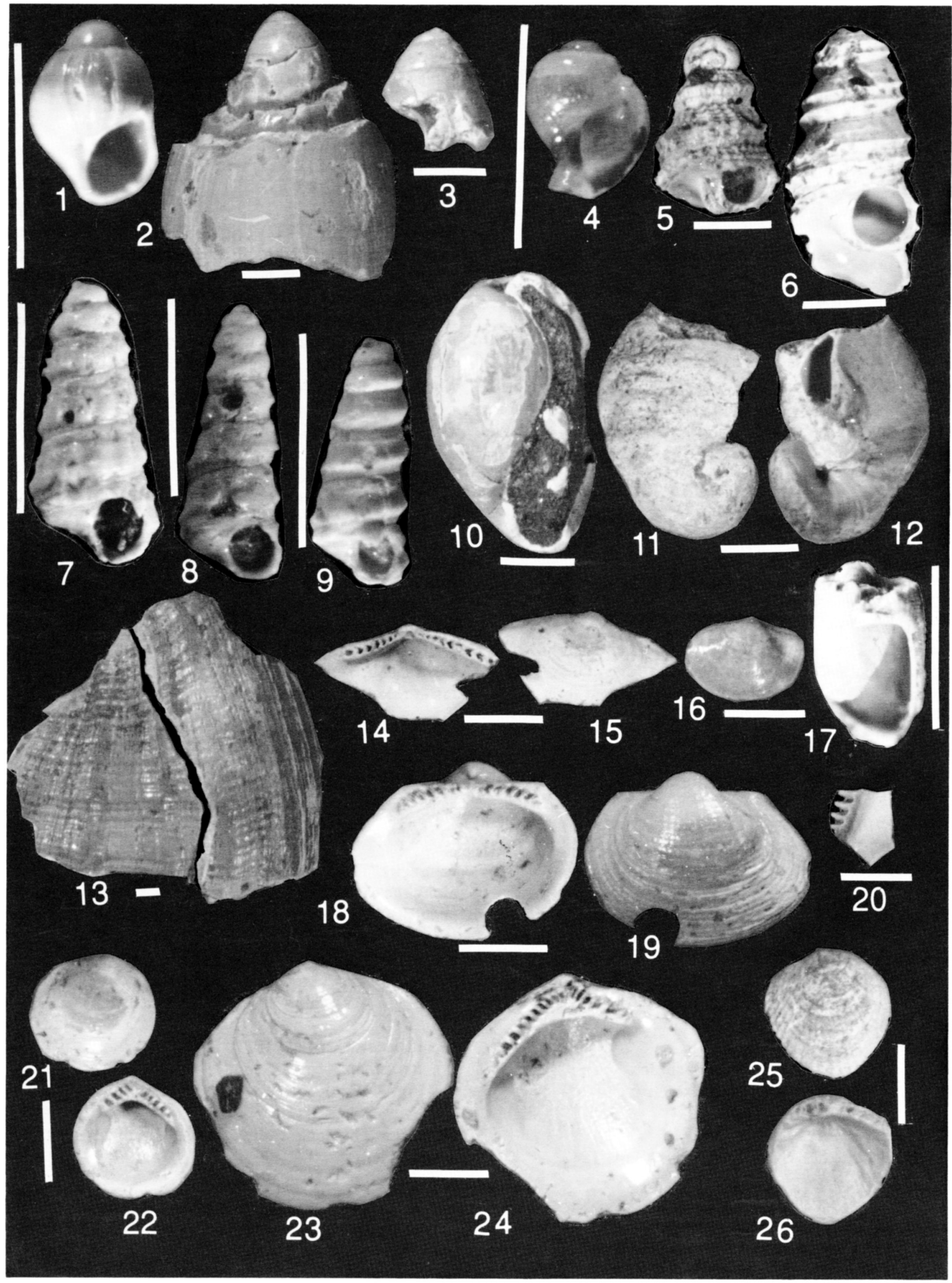


Levels: The former is from $470 \mathrm{~m}$ (Oligocene), the second was caved to $1035 \mathrm{~m}$, in Upper Cretaceous material.

\section{Buccinid sp.}

Fig. 8.21

Remarks: This indeterminate taxon ranges in size from 2 to $5 \mathrm{~mm}$ in length.

Levels: $460,455 \mathrm{~m}$. Small numbers appear in the lower section of the Oligocene.

\section{Family Olividae Latreille, 1825}

\section{Genus Olivella Swainson, 1831}

Olivella cf. O. mutica (Say, 1822)

Fig. 8.22

Remarks: The present range of $O$. mutica is from North Carolina to Texas and the West Indies according to Richards (1962) suggesting an affinity for warm, probably shallow waters. Our single specimen is $3 \mathrm{~mm}$ in length.

Levels: 495 m (upper Middle Eocene).

Family Cancellariidae Forbes and Hanley, 1853

Genus Agatrix R. Petit, 1967

Agatrix cf. A. agassizii (Dall, 1889)

Fig. 8.23

Remarks: The present range of $A$. agassizii is from North Carolina to the Caribbean, at depths of 35 to $100 \mathrm{~m}$. This is probably an adult example of a closely-related form $5 \mathrm{~mm}$ in length.

Levels: 405 m (Oligocene).

Family Turridae Swainson, 1840

Genus Drilliola Cossman, 1903

Drilliola cf. D. pulchella (Verrill, 1880)

Fig. 8.16

Remarks: Verrill (1882) reported D. pulchella (= Taranis pulchella) from $1000 \mathrm{~m}$ depth off Massachusetts. Our wellpreserved specimen is virtually identical to the one illustrated in Abbott, (1974). Its known depth habitat and good condition strongly suggest that it was living at the site.

Levels: 365 m (Oligocene).

\section{Order Cephalaspidea \\ Family Pyramidellidae Gray, 1840}

Genus Odostomia Fleming, 1813

Odostomia cf. O. laevigata d'Orbigny, 1842

Fig. 8.26

Remarks: The present geographic range of $O$. laevigata is from North Carolina to the West Indies. Abbott (1974) fur- ther indicates that this species is ectoparasitic on other marine molluscs and worms.

Levels: Two widely separated samples, at $485 \mathrm{~m}$ (Oligocene) and $885 \mathrm{~m}$ (Lower Eocene). It seems possible that the lower occurrence is caved.

\section{Genus Turbonilla Risso, 1826}

Turbonilla cf. T. emertoni Verrill, 1882

Fig. 8.27, 8.28

Remarks: Verrill (1882) originally described $T$. emertoni from $500 \mathrm{~m}$ water depth off Massachusetts, suggesting an affinity for cool, deep water. Our very similar specimens are generally less than $2 \mathbf{~ m m}$ in length.

Levels: $775,755,650,635,625,620,410,210 \mathrm{~m}$. Occurs in levels from Lower Eocene to Lower Miocene. The former finds may represent cavings from the lower Middle Eocene, where it is most plentiful.

\section{Family Acteonidae d'Orbigny, 1842}

Genus Acteon de Montfort, 1810

Acteon cf. A. punctostriatus (C.B. Adams, 1840)

Fig. 8.29

Remarks: $A$. punctostriatus is presently found from Massachusetts to Argentina, from the low tide line to $120 \mathrm{~m}$. Most of our specimens are 1 to $2 \mathrm{~mm}$ in length. The shallow habitat of the modern form suggests that our variety may be present as a transported element in CP1 P-51's Tertiary section. Levels: $660,625,530,445,200 \mathrm{~m}$. Occurs sporadically from lower Middle Eocene up to Lower Miocene.

Family Cylichnidae A. Adams, 1850

Genus Cylichna Loven, 1846 Cylichna cf. C. eburnea Verrill, 1885

Fig. 9.10

Remarks: The modern geographic range of $C$. eburnea is along the eastern seaboard of the United States, to defth of about $150 \mathrm{~m}$. Our very similar specimen is about $3.5 \mathrm{~mm}$ in length.

Levels: 495 m (upper Middle Eocene).

Family Retusidae Thiele, 1925

Genus Retusa Brown, 1827

Retusa sp.

Fig. 9.17

Remarks: This lone, badly damaged specimen is just over $1 \mathrm{~mm}$ in length.

Levels: 690 m (Lower Eocene). 
Miscellaneous gastropods

Figs. 8.20, 8.25, 8.30, 8.31, 9.1 to 9.5

Remarks: These are damaged or juvenile specimens that have not been identified as to genus.

Levels: Found in most samples throughout the studied interval.

Class Scaphopoda Bronn, 1862

Family Dentaliidae Gray, 1834

Genus Dentalium Linné, 1758

Dentalium cf. D. callithrax Dall, 1889

Fig. 7.9, 7.10

Remarks: $D$. callithrax is presently found from North Carolina to the West Indies, at depths of 400 to $3200 \mathrm{~m}$. Our specimens are broken fragments, some as much as $13 \mathrm{~mm}$ in length. Levels: $875,830,815,800,785,755,730,720,715,705$, $700,685,680,670,665,660,655,640,635,485,455,435$, $390,385,370,355,350,230 \mathrm{~m}$. Fairly common in the Oligocene and most of the Eocene.

\section{Dentalium cf. D. laqueatum Verrill, 1885}

Fig. 7.11, 7.12

Remarks: The modern distribution of $D$. laqueatum is the same as for $D$. callithrax, but in shallower water, from 8 to $400 \mathrm{~m}$ depth. Our single specimen is a $1 \mathrm{~mm}$ broken segment.

Levels: 685 m (topmost Lower Eocene).

\section{Dentalium occidentale Stimpson, 1851}

Fig. 7.20

Remarks: At present, D. occidentale is found from Newfoundland to North Carolina, at depths from 40 to $2000 \mathrm{~m}$. It is one of the single most common molluscan taxa in the Cenozoic section of CP1 P-51, usually appearing as a smoothwalled, calcareous tube, round in cross-section, representing a fragment of a whole shell.

Levels: $D$. occidentale is found in most levels of the well, less commonly in the Lower Eocene and Paleocene.

\section{Dentalium sp.}

Fig. 7.13, 7.14

Remarks: Only fragments of this taxon occur, and it could be one of several species. It is round in cross-section, with 10 to 12 weak ribs, with concave spaces between them. Most fragments are only 1 to $2 \mathrm{~mm}$ in length.

Levels: 930, 630, 620, 245, 225, $205 \mathrm{~m}$. A few specimens appear in levels from Eocene to Lower Miocene.
Family Siphonodentaliidae Simroth, 1894

\section{Genus Cadulus Philippi, 1844}

Cadulus cf. C. platensis Henderson, 1920

Fig. 7.21

Remarks: Members of this genus exhibit bulbous swellings in the centre of the shell, and are all inhabitants of deep water in relatively low latitudes. $C$. platensis is now present from Georgia to Florida in depths to $1300 \mathrm{~m}$. As with the other scaphopods, our specimens tend to be fragments of shells, in this species usually about $1 \mathrm{~mm}$ in length.

Levels: $910,785,675,540 \mathrm{~m}$. A few specimens, in Middle and Lower Eocene strata.

\section{Class Uncertain \\ ? Family Coleolidae Fisher, 1962}

\section{? Genus Coleolus Hall, 1879 \\ ? Coleolus sp.}

Fig. 7.15, 7.16

Remarks: This form occurs as a tapering calcareous tube, with very fine, oblique striations. Our specimens are generally 1 to $2 \mathrm{~mm}$ in length. The known stratigraphic range of Hall's original enigmatic fossil is Silurian to Carboniferous and it is believed to represent a pelagic organism (Fisher, 1962). Syssoiev (1957) placed Coleolus in the Mollusca, on the basis of its apparent close resemblance to scaphopod shells, a similarity shared by our taxon.

There is a strong resemblance to Hall's (1879) Coleolus, with its oblique striations. In view of the known Paleozoic range of this genus, however, such an identification would have to be considered extremely tentative; therefore we consider our form to be an unrelated homeomorph.

Levels: Present in most samples from 990 to $665 \mathrm{~m}$. Also $525,510,505,490$ and $465 \mathrm{~m}$. Present in most Paleocene and Lower Eocene samples, less common in Middle Eocene and Oligocene sections.

\section{Class Bivalvia \\ Order Nuculacea \\ Family Nuculidae Gray, 1824}

\section{Genus Yoldia (Moller, 1842) \\ Yoldia myalis (Couthouy, 1838) \\ Fig. 9.14, 9.15}

Remarks: Richards (1962) gives the present Atlantic range of $Y$. myalis as Labrador to Cape Cod. Abbott (1974) gives Hudson Strait to Massachusetts, 20 to $150 \mathrm{~m}$. This is apparently a cool-water species.

Levels: $285,235,220,215 \mathrm{~m}$. A few specimens occur in or just below Lower Miocene sediments. 
Genus Portlandia Morch, 1857 Portlandia cf. P. fraterna (Verrill and Bush, 1898) Fig. 9.16

Remarks: At present $P$. fraterna is found from the Gulf of St. Lawrence to Georgia, at depths of 200 to $3200 \mathrm{~m}$. Our specimens are between 1 to $2 \mathrm{~mm}$ in length.

Levels: 235, 230, $220 \mathrm{~m}$. Lower Miocene.

\section{Taxodont hinge fragment}

Fig. 9.20

Remarks: Numerous fragments of this type are found in several sections of the core.

Levels: $815,710,695,615,610,595,585,485,455,400$, $320,305,275,255,245,240,235,225,220,210,205,200$, $190 \mathrm{~m}$. Eocene, Oligocene, and most commonly in Lower Miocene.

\section{Order Arcacea}

Family Arcidae Lamarck, 1809

\section{Genus Bathyarca Kobelt, 1891}

Bathyarca centenaria (Say, 1824)

Fig. 9.18, 9.19

Remarks: Conrad (in Harris, 1893) reported B. centenaria from the Upper Tertiary (Miocene) of eastern North America. It is very similar to, and may be synonymous with $B$. pectunculoides (Scacchi), a species now found from the Gulf of St. Lawrence to Massachusetts, at depths of 50 to 1000 $\mathrm{m}$. The few specimens in this site may be in situ, given the present depth range of the extant form.

Levels: $670,650 \mathrm{~m}$. A few specimens appear in two lower Middle Eocene samples.

Family Glycymerididae Newton, 1922

Genus Glycymeris da Costa, 1778

Glycymeris cf. G. americana (DeFrance, 1826)

Fig. 9.21 to 9.24

Remarks: Richards (1962) gives the present distribution of G. americana as from North Carolina to the West Indies and Texas. Abbott (1974) gives the range as North Carolina to Brazil, 3 to $40 \mathrm{~m}$ water depth. Some of our specimens are up to $3 \mathrm{~mm}$ in diameter. This could well be a part of a transported fauna from warmer, neritic sources.
Levels: $740,700,690,685,675,665,660,655,650,640$, $630,625,620,615,610,600,595,590,575,480,460 \mathrm{~m}$. Common in the lower Middle Eocene.

Glycymeris cf. G. subtilis (Nicol, 1956)

Fig. 9.25, 9.26

Remarks: Abbott (1974) reports G. subtilis as from Bermudan waters, at 100 to $200 \mathrm{~m}$ depth. Our specimens average only 1 to $2 \mathrm{~mm}$ in in size.

Levels: $655,585,380,375,355 \mathrm{~m}$. Scattered specimens in Middle Eocene and Oligocene.

\section{Indeterminate Glycymerid hinge fragment}

Fig. 10.1, 10.2

Remarks: This 4-mm long hinge-line fragment appears to belong to the Glycymerid family.

Levels: 595 m (Middle Eocene).

\section{Order Mytiloida \\ Family Mytilidae Rafinesque, 1815}

Genus Dacrydium Torell, 1859

Dacrydium vitrium (Holbőll, in Möller, 1842)

Fig. 10.3, 10.4

Remarks: This wide-ranging species currently occurs from Greenland south to the Gulf of Mexico, in water from 12 to $3200 \mathrm{~m}$ depth. The excellent, "fresh" condition of the two specimens of this small, delicate species suggest that they may have been caved to their present positions from much younger, possibly Recent levels.

Levels: 925, $565 \mathrm{~m}$ (Eocene).

\section{Order Pteroida Family Ostreidae Rafinesque, 1815}

\author{
Genus Crassostrea Sacco, 1897 \\ Crassostrea cf. C. virginica (Gmelin, 1791) \\ Fig. 10.5, 10.6
}

Remarks: The modern range of this well-known, edible species is from the Gulf of St. Lawrence to the West Indies, usually in less than $100 \mathrm{~m}$ of water. Our specimens appear identical to the modern form, but are obviously juvenile.

Levels: 710, 595, 590, $555 \mathrm{~m}$. Few specimens, in Middle and Lower Eocene.

Fig. 10. Bivalves. Scale bar $=1 \mathrm{~mm} .(10.1,10.2)$ Indeterminate Glycymerid hinge fragment from $595 \mathrm{~m}$. GSC no. 78564 . (10.3, 10.4) Dacrydium vitreum from $925 \mathrm{~m}$. GSC no. 78565.10 .3 interior of valve, 10.4 exterior. (10.5, 10.6) Crassostrea cf. C. virginica from $595 \mathrm{~m}$. GSC no. 78566. 10.5 interior of valve, 10.6 exterior. $(10.7,10.8)$ Lucina cf. L. radians from $210 \mathrm{~m}$. GSC no. 78567.10. exterior of valve, 10.8 interior. $(10.9,10.10)$ Astarte cf. A. undata $665 \mathrm{~m}$. GSC no. 78568.10 .9 exterior of valve, 10.10 interior. (10.11) Clinocardium ef. C. ciliatum fragment from $595 \mathrm{~m}$. GSC no. 78569 . $(10.12,10.13)$ Mulinia cf. M. lateralis from $220 \mathrm{~m}$. GSC no. 78570.10 .12 exterior of valve, 10.13 interior. $(10.14,10.15)$ Tellina cf. T. agilis from $195 \mathrm{~m}$. GSC no. 78571 . 10.14 exterior of valve, 10.15 interior. (10.16) Mercenaria ef. M. mercenaria hinge fragment $195 \mathrm{~m}$. GSC 78572 . Note pitted, corroded condition. (10.17, 10.18) Liocyma cf. L. fluctuosa from $220 \mathrm{~m}$. GSC no. 78573.10 .17 interior of valve, 10.18 exterior. (10.19, 10.20) Indeterminate bivalve from $215 \mathrm{~m}$. GSC no. 78574.10 .19 interior of valve, 10.20 exterior. 


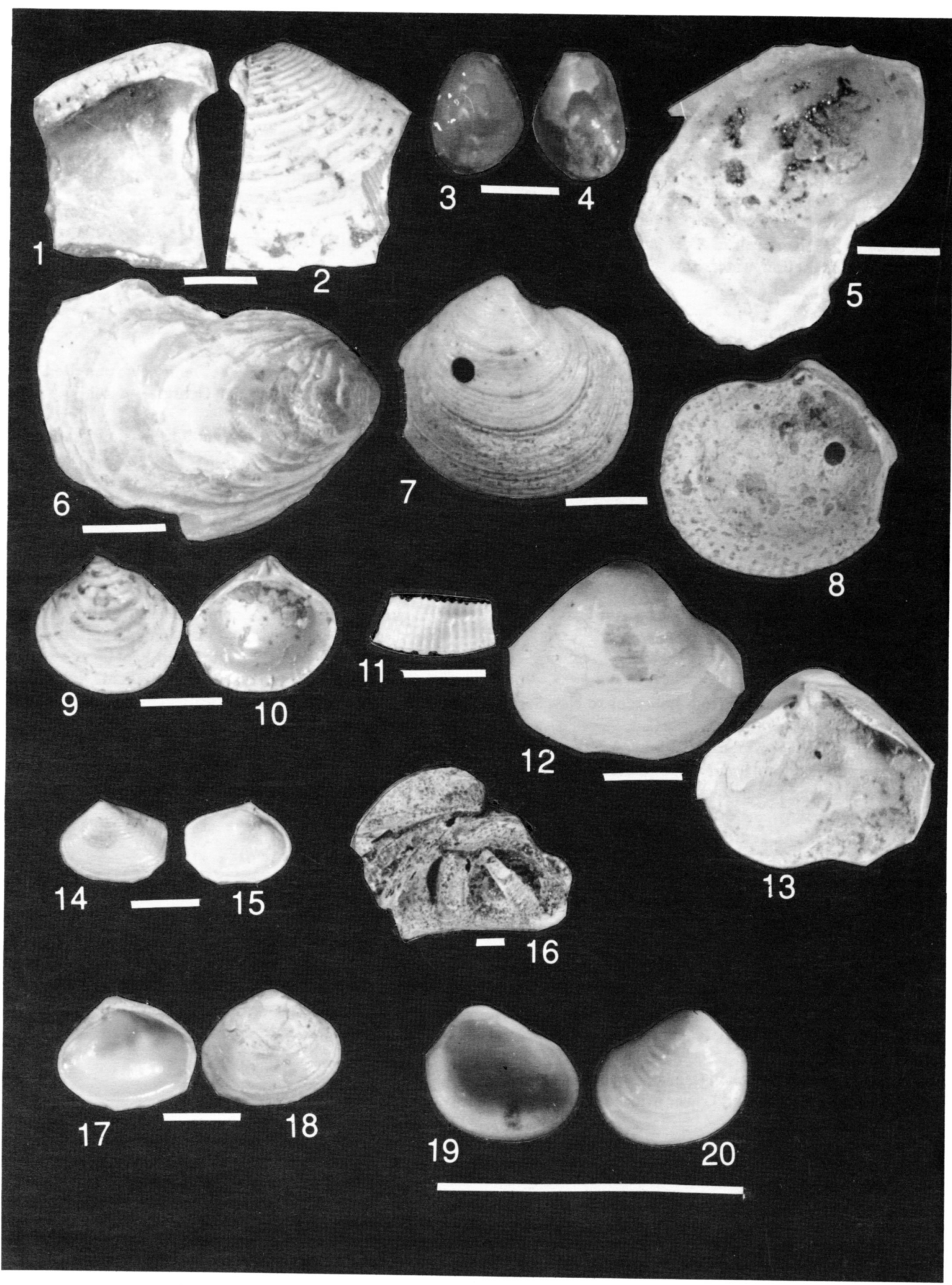




\section{Order Heterodonta \\ Family Lucinidae Fleming, 1828}

Genus Lucina Bruguiere, 1797

Lucina cf. L. radians Con rad, 1841

Fig. 10.7, 10.8

Remarks: Richards (1962) gives the current distribution of L. radians ( $=$ Phacoides radians (Conrad)) as North Carolina to the West Indies. Abbott (1974) agrees, giving a depth range of 10 to $170 \mathrm{~m}$. This is another form normally associated with warm, shallow water, and so may be transported downslope in CP1 P-51.

Levels: 285, 245, 225, 220, 215, $210 \mathrm{~m}$. Few specimens in Lower Miocene levels and just below.

\section{Family Thyasiridae Dall, 1901}

\section{Indeterminate bivalve}

Fig. 10.19, 10.20

Remarks: This $0.5 \mathrm{~mm}$ specimen is very similar to the genus Thyasira, but lacks the diagnostic folding.

Levels: 220 m (Lower Miocene).

\section{Family Astartidae d'Orbigny, 1844}

Genus Astarte J. Sowerby, 1816

Astarte cf. A. undata Gould, 1841

Fig. 10.9, 10.10

Remarks: $A$. undata ranges from Labrador to New Jersey, from 10 to $200 \mathrm{~m}$ water depth.

Levels: 700, 690, 665, 275, 245, $225 \mathrm{~m}$. A few specimens of our closely related form occur at the Lower-Middle Eocene boundary and in and just below the Lower Miocene.

\section{Family Carditidae Oken, 1818}

\section{Genus Clinocardium Keen, 1936}

Clinocardium cf. C. ciliatum (Fabricius, 1780)

Fig. 10.11

Remarks: Feyling-Hansen (1955) gives the present geographic range of $C$. ciliatum as circum-Arctic, including Greenland to Massachusetts on the Atlantic coast, as does Richards (1962), and reports it to be more common in waters greater than $50 \mathrm{~m}$ depth.

Levels: $595,190 \mathrm{~m}$. A few small fragments appeared in widely scattered Middle Eocene and Lower Miocene levels.
Genus Mulinia Gray, 1837

Mulinia cf. M. lateralis (Say, 1822)

Fig. 10.12, 10.13

Remarks: Richards (1962), gives the present distribution of $M$. lateralis as New Brunswick to Texas and the West Indies. Abbott (1974) gives Maine to Florida, in shallow water. Our single, damaged specimen is about $3 \mathrm{~mm}$ in length. Levels: 220 m (Lower Miocene).

Family Tellinidae de Blainvillẹ, 1814

Genus Tellina Linné, 1758

Tellina cf. T. agilis Stimpson, 1858

Fig. 10.14, 10.15

Remarks: The present range of $T$. agilis is from the Gulf of St. Lawrence south to coastal Georgia, in shallow water, subtidal to $100 \mathrm{~m}$ depth.

Levels: Few specimens at 195 and 215 m (Lower Miocene).

Family Veneridae Rafinesque, 1815

Genus Mercenaria Schumacher, 1817

Mercenaria cf. M. mercenaria (Linné, 1758)

Fig. 10.16

Remarks: $M$. mercenaria, commonly called the Northern Quahog, is a tolerant species today found from the Gulf of St. Lawrence to Florida, offshore, but usually in less than $100 \mathrm{~m}$ depth. Our specimens are all fragments, identifiable by their relative thickness and sometimes by the hinge structure, as in the figured specimen.

Levels: $470,275,265,245,240,235,230,225,220,215$, $205,200,195,190,180 \mathrm{~m}$. One of the more common molluscs in Lower Miocene strata. Its few occurrences further down could be attributed to caving.

Genus Liocyma Dall, 1870

Liocyma cf. L. fluctuosa (Gould, 1841)

Fig. 10.17, 10.18

Remarks: In the modern Atlantic, the cool-water $L$. fluctuosa ranges from Greenland to Nova Scotia, in waters to $400 \mathrm{~m}$ depth and Feyling-Hansen (1955) reports it as circum-Arctic. Our single specimen is about $1.5 \mathrm{~mm}$ in length. Levels: 220 m (Lower Miocene). 